IMMOBILIZATION OF TYROSINASE IN POLYSILOXANE/POLYPYRROLE

COPOLYMER MATRICES

A THESIS SUBMITTED TO

THE GRADUATE SCHOOL OF NATURAL AND APPLIED SCIENCES

OF

MIDDLE EAST TECHNICAL UNIVERSITY

BY

AHU ARSLAN

IN PARTIAL FULFILLMENT OF THE REQUIREMENTS

FOR

THE DEGREE OF MASTER OF SCIENCE

IN CHEMISTRY

JANUARY 2006 
Approval of the Graduate School of Natural and Applied Sciences

Prof. Dr. Canan Özgen Director

I certify that this thesis satisfies all the requirements as a thesis for the degree of Master of Science.

Prof. Dr. Hüseyin İşçi

Head of Department

This is to certify that we have read this thesis and that in our opinion it is fully adequate, in scope and quality, as a thesis for the degree of Master of Science.

Prof. Dr. Levent Toppare Supervisor

Examining Committee Members

Prof. Dr. Levent Toppare (METU,CHEM)

Prof. Dr. Duygu Kısakürek (METU, CHEM)

Prof. Dr. Zuhal Küçükyavuz (METU, CHEM)

Prof. Dr. Mustafa Güllü (Ankara Unv. CHEM)

Dr. Senem Kiralp 
I hereby declare that all information in this document has been obtained and presented in accordance with academic rules and ethical conduct. I also declare that, as required by these rules and conduct, I have fully cited and referenced all material and results that are not original to this work.

Name, Last name :

Signature 


\title{
ABSTRACT \\ IMMOBILIZATION OF TYROSINASE IN POLYSILOXANE/POLYPYRROLE COPOLYMER MATRICES
}

\author{
Arslan, Ahu \\ M.Sc., Department of Chemistry \\ Supervisor : Prof. Dr. Levent Toppare
}

January 2006, 58 pages

Immobilization of tyrosinase in conducting copolymer matrices of pyrrole functionalized polydimethylsiloxane/polypyrrole (PDMS/PPy) were achieved by electrochemical polymerization. The polysiloxane/polypyrrole/tyrosinase electrode was constructed by the entrapment of enzyme in conducting matrices during electrochemical copolymerization. Maximum reaction rate $\left(\mathrm{V}_{\max }\right)$ and MichaelisMenten constant $\left(\mathrm{K}_{\mathrm{m}}\right)$ were investigated for immobilized enzyme. Enzyme electrodes were prepared in two different electrolyte/solvent systems. The effect of supporting electrolytes, p-toluene sulfonic acid and sodium dodecyl sulfate on the enzyme activity and film morphology were determined. Temperature and $\mathrm{pH}$ optimization, operational stability and shelf-life of enzyme electrodes were also examined. Phenolic contents of green and black tea were determined by using enzyme electrodes.

Keywords: Immobilization, tyrosinase, conducting copolymers, polysiloxane, enzyme electrode 


\title{
ÖZ \\ TYROSINAZIN POLISILIOKSAN/POLIPIROL KOPOLIMER MATRISLERINDE İMMOBILLIZASYONU
}

\author{
Arslan, Ahu \\ Yüksek Lisans, Kimya Bölümü \\ Tez Yöneticisi : Prof. Dr. Levent Toppare
}

Ocak 2006, 58 sayfa

Tyrosinazın pirolle fonksiyonlandırılmış polidimetilsiloksan/polipirol (PDMS/PPy) iletken kopolimeri içerisinde immobilizasyonu elektrokimyasal polimerizasyon ile başarıldı. Polisiloksan/polipirol/tyrosinaz elektrodu enzimin iletken matris içerisine elektrokimyasal kopolimerizasyon sirasında tutuklanması ile yapıldı. Maximum reaksiyon hızı $\left(\mathrm{V}_{\max }\right)$ ve Michaelis-Menten sabiti $\left(\mathrm{K}_{\mathrm{m}}\right)$ immobilize edilmiş enzim için araştırıldı. Enzim elektrodları iki farklı elektrolit/çözücü sisteminde hazırlandı. p-toluen sulfonik asit ve sodium dodesil sülfat destek elektrolitlerinin enzim aktivitesi ve film morfolojisi üzerindeki etkisi araştırıldı. Enzim elektrodları için sıcaklık ve pH optimizasyonu, kullanım ve saklama kararlılığı araştırıldı. Siyah ve yeşil çay içerisindeki fenolik içeriği enzim elektrodları kullanılarak tayin edildi.

Anahtar Kelimeler: İmmobilizasyon, tirosinaz, iletken kopolimerler, polisiloksan, enzim elektrod. 
To My Mother, Nilay Arslan 


\section{ACKNOWLEDGMENTS}

I would like to express my appreciation to Prof. Dr. Levent Toppare for his support, continuous guidance and encouragement throughout my studies. In the direction of his comments and advices, I learned a lot of things from him not only the chemistry but also the life.

I would also like to thank Dr. Senem Kiralp for her assistance, endless help and being my friend.

I would like to thank to our group members for their friendship and cooperation.

I would like to give my special thanks to my family, especially to my mother Nilay Arslan, for her continuous support and trust. I could not achieve anything without them.

Finally, thanks also should go to my love, Ümit Hakan Yıldı, for his continuous support, encouragement and insight throughout my research and special thanks also for his sensibility, understanding and tolerance for me during this period.

I also wish to thank to my colleagues in Chemistry Department of METU. 


\section{TABLE OF CONTENTS}

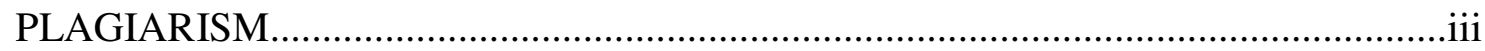

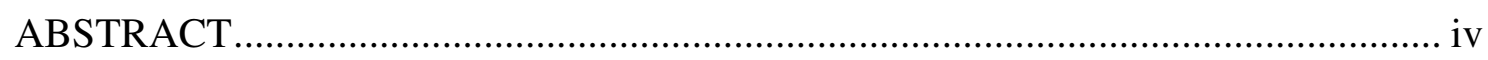

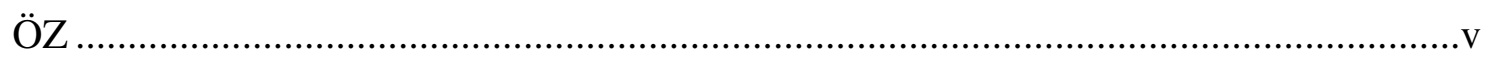

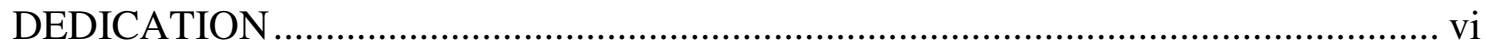

ACKNOWLEDGMENTS ............................................................................. vii

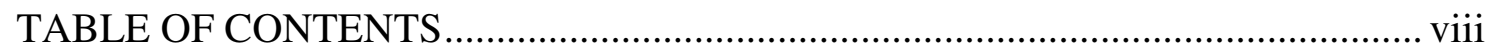

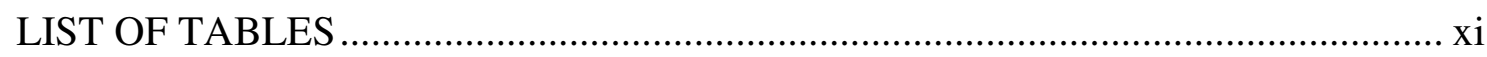

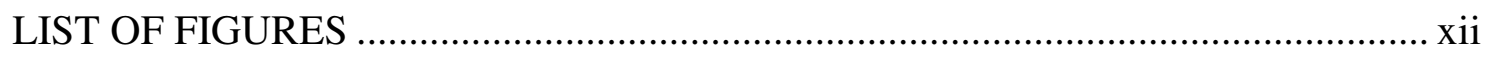

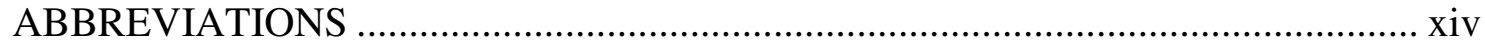

\section{CHAPTERS}

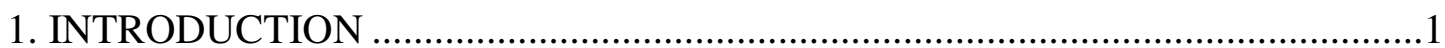

1.1 Conducting Polymers .......................................................................

1.1.1 History of Conducting Polymers ....................................................

1.1.2 Theory of Conducting Polymers .......................................................

1.1.3 Synthesis of Conducting Polymers ........................................................6

1.1.3.1 Chemical Synthesis of Conducting Polymers ...............................6

1.1.3.2 Electrochemical Synthesis of Conducting Polymers ......................6

1.1.3.3 Electropolymerization of Heterocyclics .....................................

1.1.4 Applications of Conducting Polymers ................................................

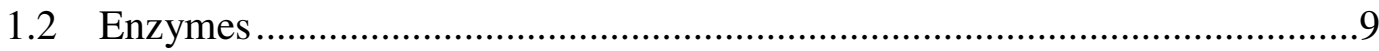

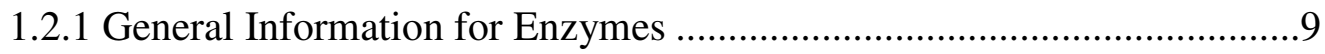




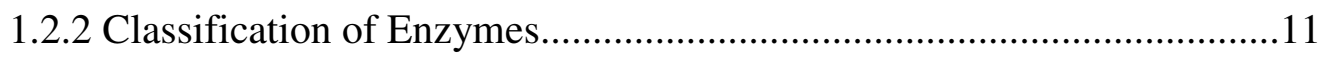

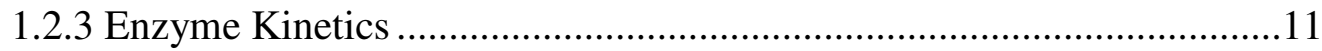

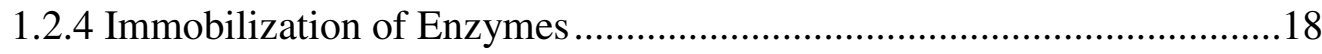

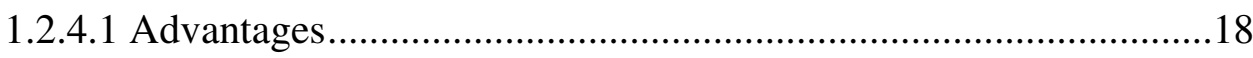

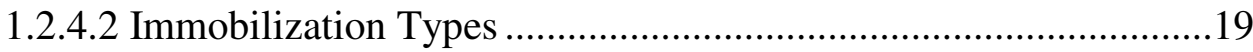

1.2.4.2.1 Covalent Bonding ...........................................................19

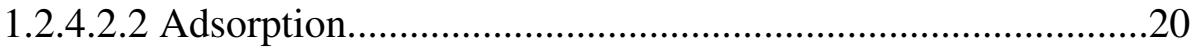

1.2.4.2.3 Intermolecular Crosslinking..............................................21

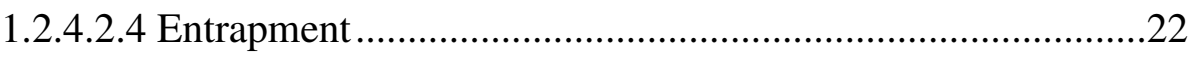

1.2.4.3 Immobilization by Electropolymerization .................................23

1.2.4.4 Applications of Immobilized Enzymes......................................24

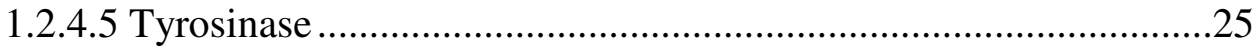

1.2.4.2 Immobilization Types .............................................................19

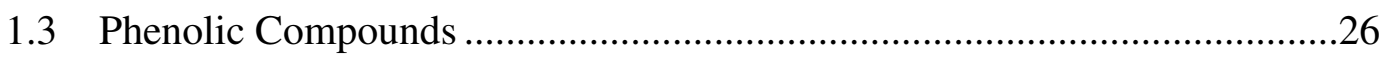

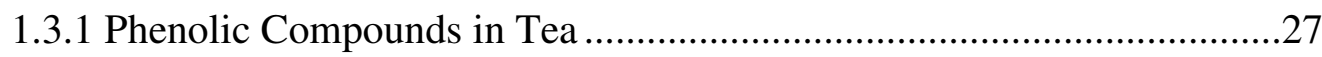

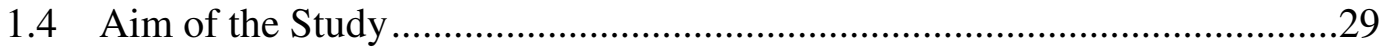

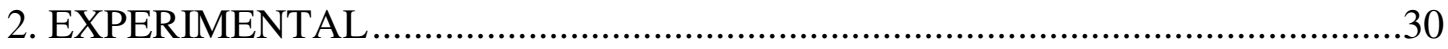

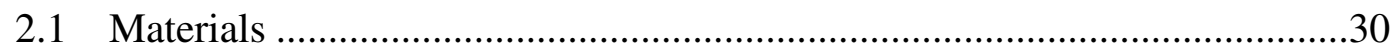

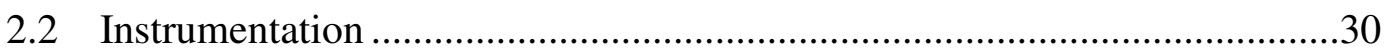

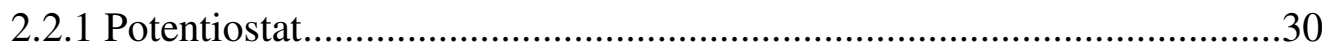

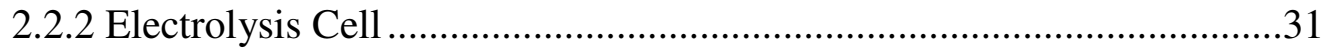

2.2.3 UV-Visible Spectrophotometer ...................................................... 31

2.2.4 Scanning Electron Microscope (SEM) …...........................................32 
2.3 Experimental Procedure

2.3.1 Immobilization of Tyrosinase in Conducting Copolymers of Polydimethylsiloxane (PDMS) .........................................................32

2.3.2 Determination of Tyrosinase Activity ...............................................33

2.3.3 Determination of Kinetic Parameters....................................................34

2.3.4 Determination of Optimum Temperature and $\mathrm{pH}$................................35

2.3.5 Determination of Operational Stability and Shelf-life...........................35

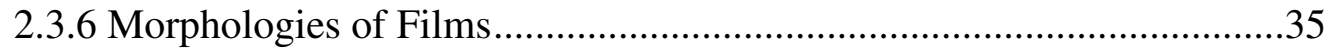

2.3.7 Investigation of Phenolic Compounds in Green and Black Tea ..............36

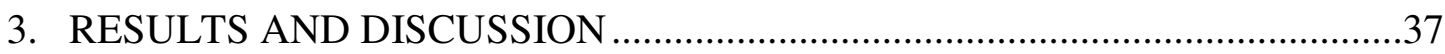

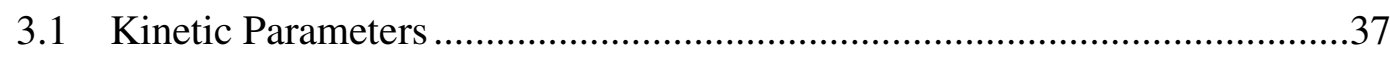

3.2 Temperature Optimization of Enzyme Electrodes....................................38

3.3 pH Optimization of Enzyme Electrodes ..................................................

3.4 Operational Stability of Enzyme Electrodes ...........................................43

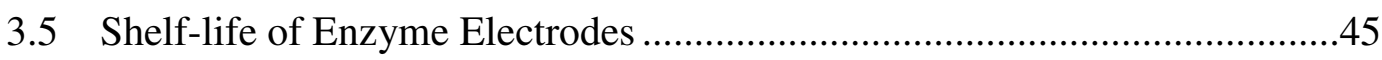

3.6 Surface Morphologies of Polymer Films ................................................46

3.7 Determination of Phenolic Compounds in Tea.........................................48

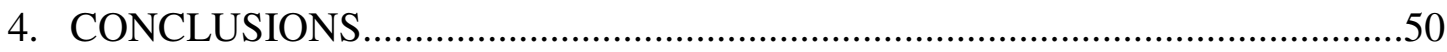

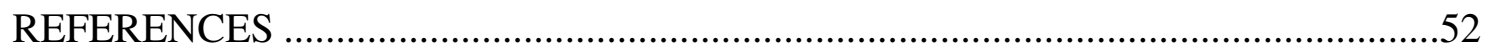




\section{LIST OF TABLES}

\section{TABLES}

Table 3.1 Kinetic parameters for free and immobilized PPO

Table 3.2 Phenolic content of black and green tea samples ....................................49 


\section{LIST OF FIGURES}

\section{FIGURES}

Figure 1.1 Schematic representation of band structure of a metal, a semiconductor and an insulator.

Figure 1.2 Structural representation of soliton, polaron and bipolaron of polyacetylene3

Figure 1.3 Schematic representation of polaron, bipolaron and bipolaron bands 4

Figure 1.4 Schematic representation of soliton and soliton bands .5

Figure 1.5 Polaron and bipolaron formation of polyacetylene .5

Figure 1.6 Proposed mechanism for the electrochemical polymerization of five membered heterocyclic monomers $(\mathrm{X}=\mathrm{NH}, \mathrm{S}, \mathrm{O})$ 8

Figure 1.7 Structural representation of a basic enzyme molecule and polypeptide bond formation. 10

Figure 1.8 Activation energy diagram of enzyme catalyzed reaction .12

Figure 1.9 Schematic representation of "key-lock" model. .13

Figure 1.10 Reaction velocity vs substrate concentration

Figure 1.11 Lineweaver-Burk plot 18

Figure 1.12 Illustration of covalent bonding method .20

Figure 1.13 Illustration of adsorption method .21 
Figure 1.14 Illustration of intermolecular crosslinking method

Figure 1.15 Illustration of entrapment method .22

Figure 1.16 Proposed mechanism for PPO catalyzed reactions .25

Figure 1.17 Chemical structures of green and black tea phenolics .28

Figure 2.1 Electrolysis cell .31

Figure 2.2 Immobilization of PPO in PDMS/PPy matrice during electrochemical polymerization 33

Figure 2.3 Schematic representation of Besthorn's Hydrazone method 34

Figure 3.1 Optimum temperatures of electrodes (a) Free PPO (b) PPy/SDS/PPO (c) PDMS/PPy/SDS/PPO (d) PPy/PTSA/PPO (e) PDMS/PPy/PTSA/PPO.40

Figure 3.2 Optimum pH of electrodes (a) Free PPO (b) PPy/SDS/PPO

(c) PDMS/PPy/SDS/PPO (d) PPy/PTSA/PPO (e) PDMS/PPy/PTSA/PPO.42

Figure 3.3 Operational stability of electrodes (a) PPy/SDS/PPO (b)PDMS/PPy/SDS/PPO (c) PPy/PTSA/PPO (d) PDMS/PPy/PTSA/PPO..44

Figure 3.4 Shelf-life of electrodes (a) PPy/SDS/PPO (b) PDMS/PPy/SDS/PPO (c) PPy/PTSA/PPO (d) PDMS/PPy/PTSA/PPO .46

Figure 3.5 SEM micrographs of (a) PDMS/PPy/SDS (b) PDMS/PPy/ PTSA
(c) PPy/PTSA

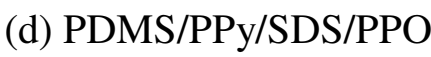
(e) PDMS/PPy/PTSA/PPO
(f) PPy/PTSA/PPO. 47 


\section{ABBREVIATIONS}

$\begin{array}{ll}\text { CB } & \text { Conduction Band } \\ \text { CCE } & \text { Constant Current Electrolysis } \\ \text { CE } & \text { Catechin Equivalence } \\ \text { CPE } & \text { Constant Potential Electrolysis } \\ \text { HOMO } & \text { Highest Occupied Molecular Orbital } \\ \text { LUMO } & \text { Lowest Unoccupied Molecular Orbital } \\ \text { MBTH } & \text { 3-methyl-2-benzothiozolinone } \\ \text { PDMS } & \text { Polydimethyl siloxane } \\ \text { PDMS/PPy } & \text { Copolymer of polydimethyl siloxane with polypyrrole } \\ \text { PPO } & \text { Polyphenol oxidase (Tyrosinase) } \\ \text { PPy } & \text { Polypyrrole } \\ \text { PTSA } & \text { p-toluene sulfonic acid } \\ \text { SDS } & \text { Sodium dodecyl sulfate } \\ \text { SEM } & \text { Scanning Electron Microscope } \\ \text { VB } & \text { Valence Band }\end{array}$




\section{CHAPTER I}

\section{INTRODUCTION}

\subsection{Conducting Polymers}

\subsubsection{History of Conducting Polymers}

The Chemistry Nobel Prize 2000 was given to Alan Heeger, Alan McDiarmid and Hideki Shirakawa for their work on conducting and conjugated polymers. The first conducting polymer synthesized was polyacetylene [1,2]. Polyacetylene is the simplest conjugated polymer. Since the first discovery of electrical conducting polymer, polyacetylene in 1977, several conjugated molecules have been investigated over the last two decades. Much of the research efforts of industrial and academic researchers have been directed to the development of new materials that are stable in conducting state, easily processable and relatively simple to produce. These new materials such as polythiophene [3,4], polyfuran [4], polypyrrole [5], polyphenylene [6], poly(phenylene vinylene) [7], polyfluorene [8], polyaniline [9] have attracted great attention.

\subsubsection{Theory of Conducting Polymers}

Conducting polymers have been the subject of research for many years as possible synthetic metals. Conjugated polymers are polyunsaturated compounds in 
which all backbone atoms are sp- or $\mathrm{sp}^{2}$-hybridized. Conjugated polymers in their neutral state are insulators or wide-gap semiconductors, and some of them behave as metallic type conductors only after a process called doping. Doping is the addition of electrons (reduction) or the removal of electrons (oxidation) from the polymer. Once doping has occurred, the electrons in the л-bond gain mobility around the polymer chain. As the electrons are moving along the molecule an electric current occurs. Via doping the conductivity of the polymer may increase 12 orders of magnitude.

The conduction mechanism of conducting polymers can be explained by band theory. Energy diagram for metal, semiconductor and insulator materials are given in Figure 1.1. The region called as valence band (VB) is the lowest energy containing highest occupied molecular orbital (HOMO), and highest energy containing lowest unoccupied molecular (LUMO) orbital is known as the conduction band $(\mathrm{CB})$. The band gap (Eg) is the energy difference between the VB and CB. In an insulator, the band gap is too high for transfer of electrons from VB to CB. Moreover, in a semiconductor the band gap is lower than insulator. High conductivity of metals is the result of very low or zero band gap [10-13]. Eg value is in the range of 0.5 to $3.0 \mathrm{eV}$ for semiconductors and bigger than $3.0 \mathrm{eV}$ for insulators.

CB

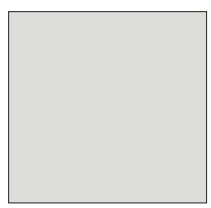

Metal

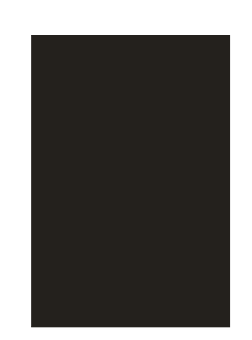

VB

Metal

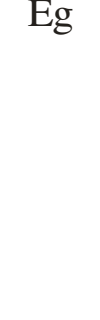

(1)
CB

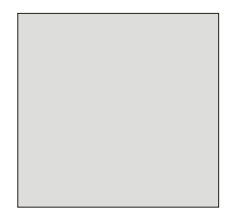

$\mathrm{Eg}$
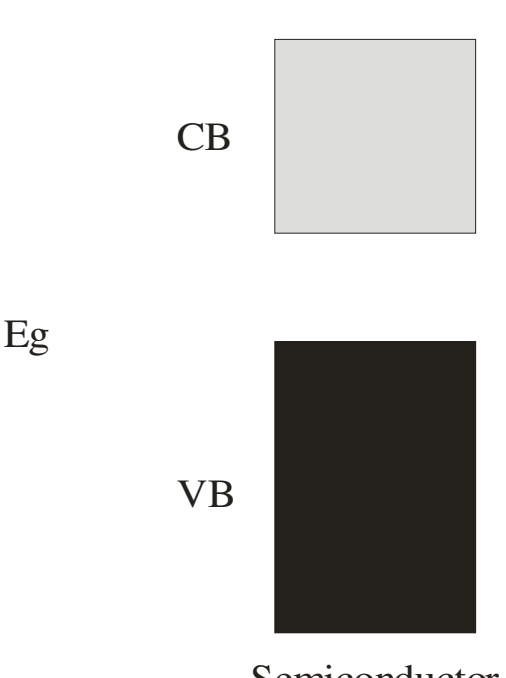

Semiconductor

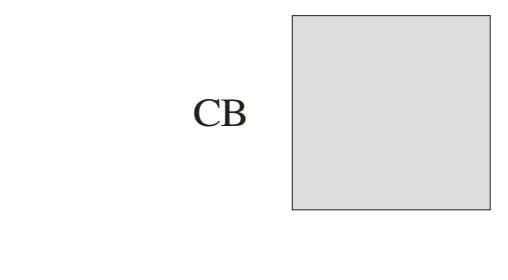

$\mathrm{Eg}$

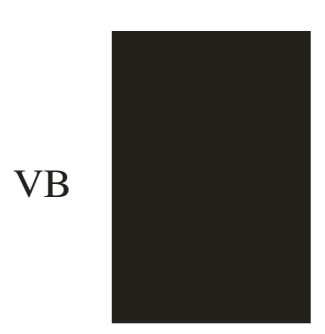

Insulator

Figure 1.1 Schematic representation of band structure of a metal, a semiconductor and an insulator. 
The two basic requirements for electronic conduction in a material are, a continuous system of a large number of strongly interacting atomic orbitals leading to the formation of electronic band structures, and the presence of an insufficient number of electrons to fill these bands.

The notions of solitons, polarons and bipolarons have supplied better understanding for the conduction mechanism of conducting polymers. [14-18]. Oxidation or reduction reactions create differences in the band structures of conducting polymer. They are solitons, polarons and bipolarons, also shown in Figure 1.2 .

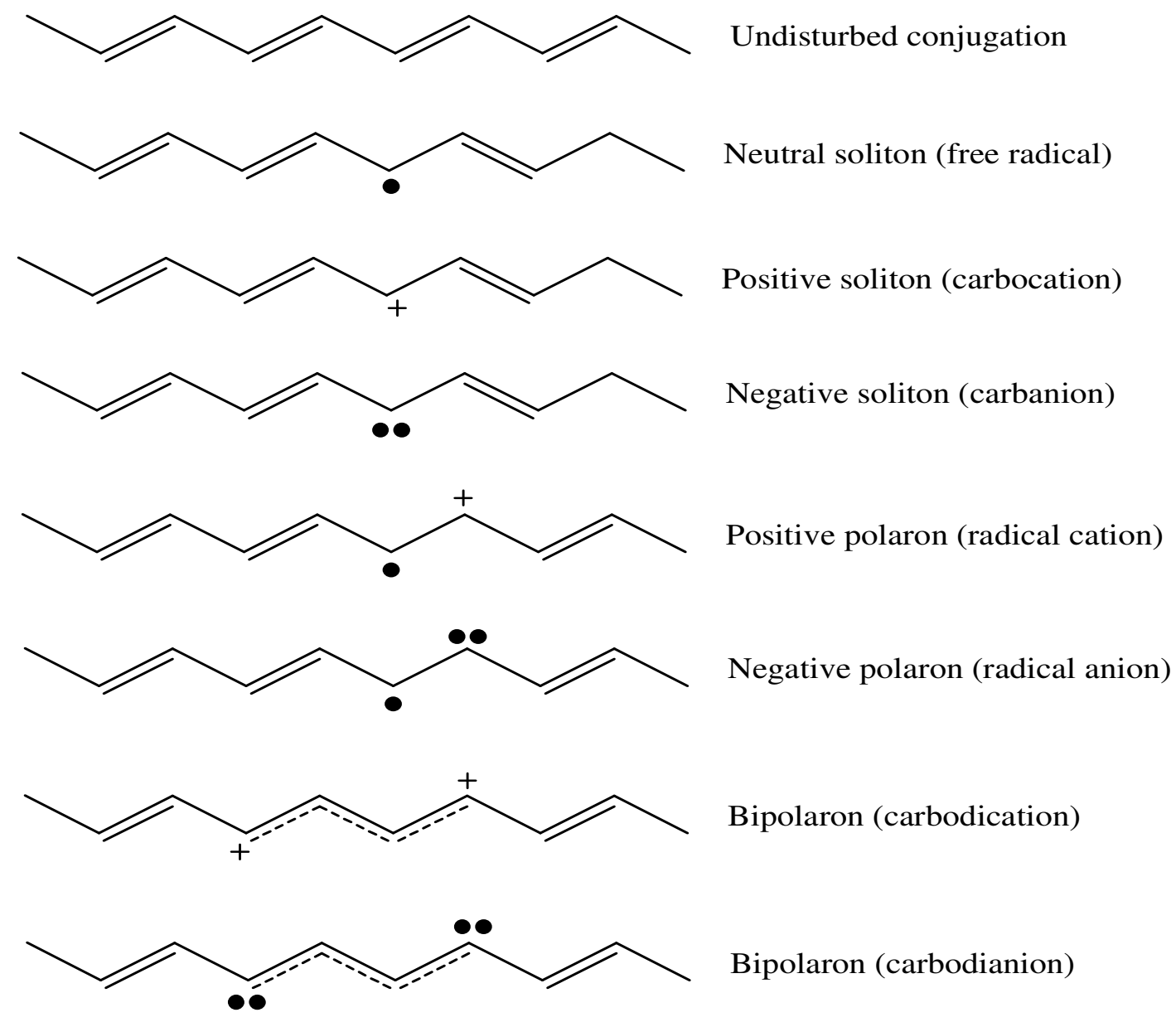

Figure 1.2 Structural representation of soliton, polaron and bipolaron of polyacetylene. 
An electron removed from the system of the polymer backbone produces free radicals and a spinless positive charge. The radical and cation are coupled to each other via local resonance of the charge and the radical. The distortion produced by this is of higher energy than the remaining portion of the chain. This combination of a charge site and a radical is called as the polaron. This could be either a radical cation or radical anion. This creates new localized electronic states in the gap, with the lower energy states being occupied by a single unpaired electron. Upon further oxidation the free radical of the polaron is removed, creating a new defect called bipolaron. This represents a lower energy than the creation of two distinct polarons. At higher doping levels it becomes possible that two polarons combine to form bipolaron. Thus, at higher doping levels the polarons are replaced by bipolarons. This eventually, with continued doping, forms into continuous bipolaron bands. For a very heavily doped polymer it is conceivable that the upper and lower bipolaron bands will merge with the VB and $\mathrm{CB}$, to produce partially filled bands and metallic like conductivity. Figure 1.3 shows the formation of polaron, bipolaron and bipolaron bands.

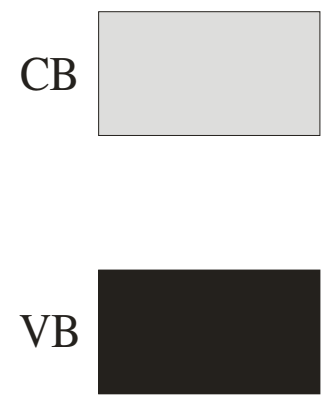

Neutral Chain
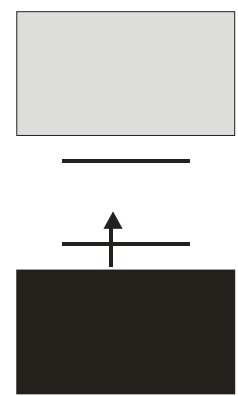

Polaron
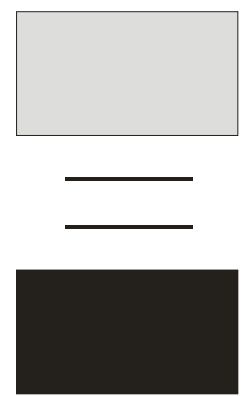

Bipolaron

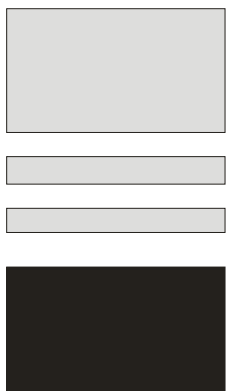

Bipolaron Bands

Figure 1.3 Schematic representation of polaron, bipolaron and bipolaron bands.

Conjugated polymers with a degenerate ground state have a slightly different mechanism. Due to the ground state structure of such polymers, the charged cations are not bound to each other and can freely separate along the chain. The effect 
of this is that the charge defects are independent of one another. These are called solitons and can be classified in three different classes as neutral, positive and negative solitons. Soliton formation results in the creation of new localized electronic states that appear in the middle of the band gap. At high doping levels, the charged solitons interact with each other to form a soliton band for metallic conductivity, shown in the Figure 1.4. Polaron and bipolaron formations as a result of oxidative doping for polyacetylene are shown in the Figure 1.5.

$\mathrm{CB}$
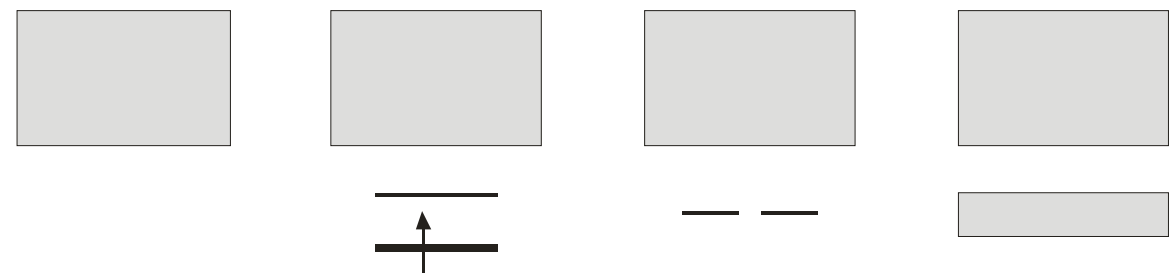

$\mathrm{VB}$

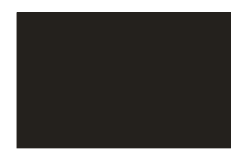

Neutral Chain

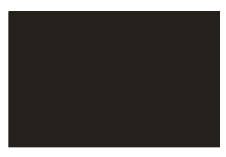

Polaron

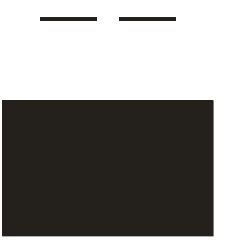

Solitons

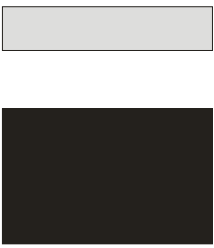

Soliton Band

Figure 1.4 Schematic representation of soliton and soliton bands.

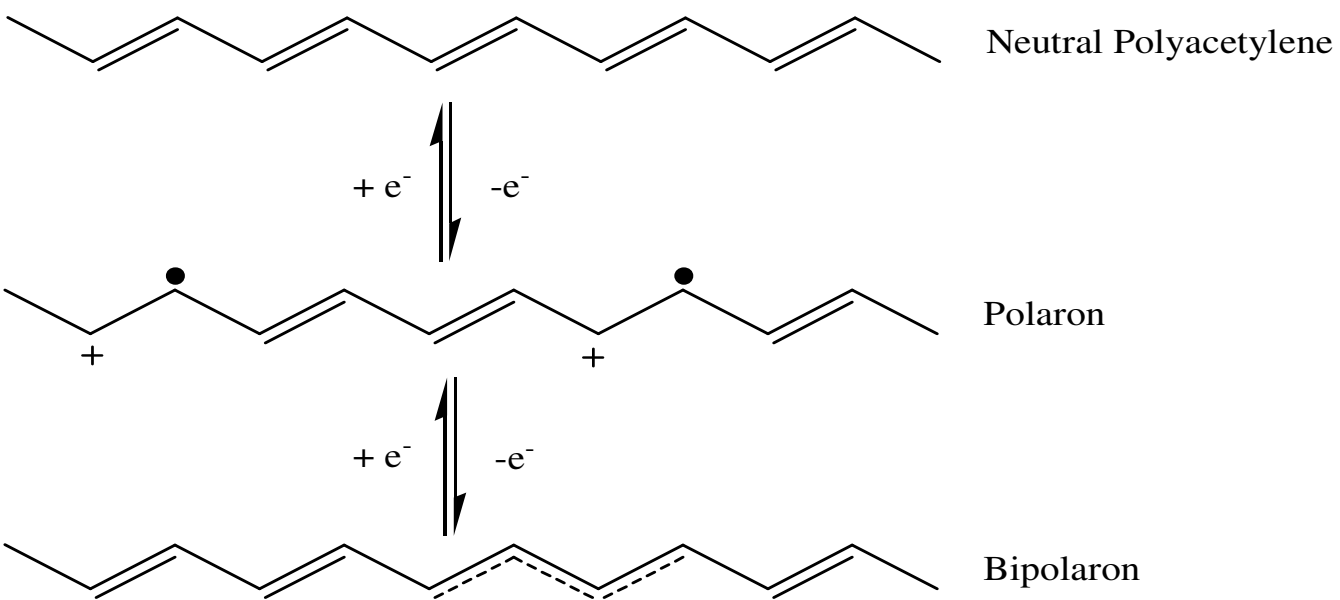

Figure 1.5 Polaron and bipolaron formation of polyacetylene. 


\subsubsection{Synthesis of Conducting Polymers}

Conducting polymers can be often synthesized from appropriate monomers by chemical or electrochemical polymerization methods. Otherwise, different synthesis routes can be applied such as photopolymerization, solid state polymerization, emulsion polymerization, plasma polymerization and pyrolysis $[19,20]$.

\subsubsection{Chemical Synthesis of Conducting Polymers}

Among the various polymerization techniques conducting polymers can be prepared by chemical polymerization. Chemical oxidation is inexpensive and also a widely used method. Chemical oxidation has several disadvantages such as yielding poor quality polymer. Also the use of strong oxidizing agents may result in the overoxidation and decomposition of polymer.

$\mathrm{Fe}^{3+}$ and $\mathrm{Cu}^{2+}$ salts are useful as catalysts for the chemical synthesis of conducting polymers such as polypyrrole (PPy) and polyaniline (PAn), and also oxygen, ozone and $\mathrm{H}_{2} \mathrm{O}_{2}$ are suitable oxidizing agents. $\mathrm{FeCl}_{3}$ and other Lewis acids can also be used for heterocyclic monomers [21-23]. For the $\mathrm{Fe}^{3+}$ catalyzed chemical polymerization, the tiny amount of $\mathrm{Fe}^{3+}$ first oxidizes the pyrrole monomer to give PPy and $\mathrm{Fe}^{3+}$ ions are reduced to $\mathrm{Fe}^{2+}$ ions. Thus, $\mathrm{Fe}^{3+}$ acts as a catalyst in the synthesis to promote the growth of PPy. Other types of iron salts, such as $\mathrm{FeCl}_{2}$, $\mathrm{Fe}\left(\mathrm{ClO}_{4}\right)_{3}, \mathrm{Fe}\left(\mathrm{ClO}_{4}\right)_{2}$ and $\mathrm{FeSO}_{4}$, can also be used to produce similar polymers. Chemical oxidation of monomer by using such kind of oxidation agent, supply the formation of conducting polymer in doped state.

\subsubsection{Electrochemical Synthesis of Conducting Polymers}

Although conducting polymers can be prepared by chemical oxidation methods, the most effective and widely used method is the electrochemical oxidation. 
The main advantage of electrochemical polymerization is to control the reaction rate and the doping process. Besides, it is simple, selective, a reproducible method, and control of film thickness and molecular weight is easy. The major disadvantage is that it yields insoluble materials by this way.

In general, techniques that used for the electrochemical synthesis of conducting polymers are potentiostatic and galvanostatic electrolyses [24]. Constant current electrolysis (CCE/Galvanostatic) is the current controlled electrolysis method. Constant potential electrolysis (CPE/Potentiostatic) allows the current change while the potential is fixed.

Electropolymerization reaction occurs by the oxidation of a monomer in a supporting electrolyte solution. Reactive radical cations are produced by applying an external potential. After initial oxidation step, two routes are possible for the formation of polymer. A radical cation of monomer can couple with a neutral monomer to form a dimer and in the second route, coupling of two radical cations form a dimer. Then, dimer is oxidized again and the process leads to the formation of electroactive polymer [24].

\subsubsection{Electropolymerization of Heterocyclics}

Schematic representation of proposed electropolymerization mechanism of heterocyclic monomers is shown in Figure 1.6. Pyrrole and thiophene are the most typical heterocyclic monomers $[25,26]$. The first step is the oxidation of monomer to form a radical cation, second step is the coupling of two radical cations to form a dimer. Then, the radical form of the dimer that is more easily oxidized than the monomer undergoes coupling with other radicals to keep on polymerization.

Polymer chains carry a charge for every fixed units of heterocyclic rings. Oxidation level depends on the nature of polymer not supporting electrolyte or other electrolysis parameters. 

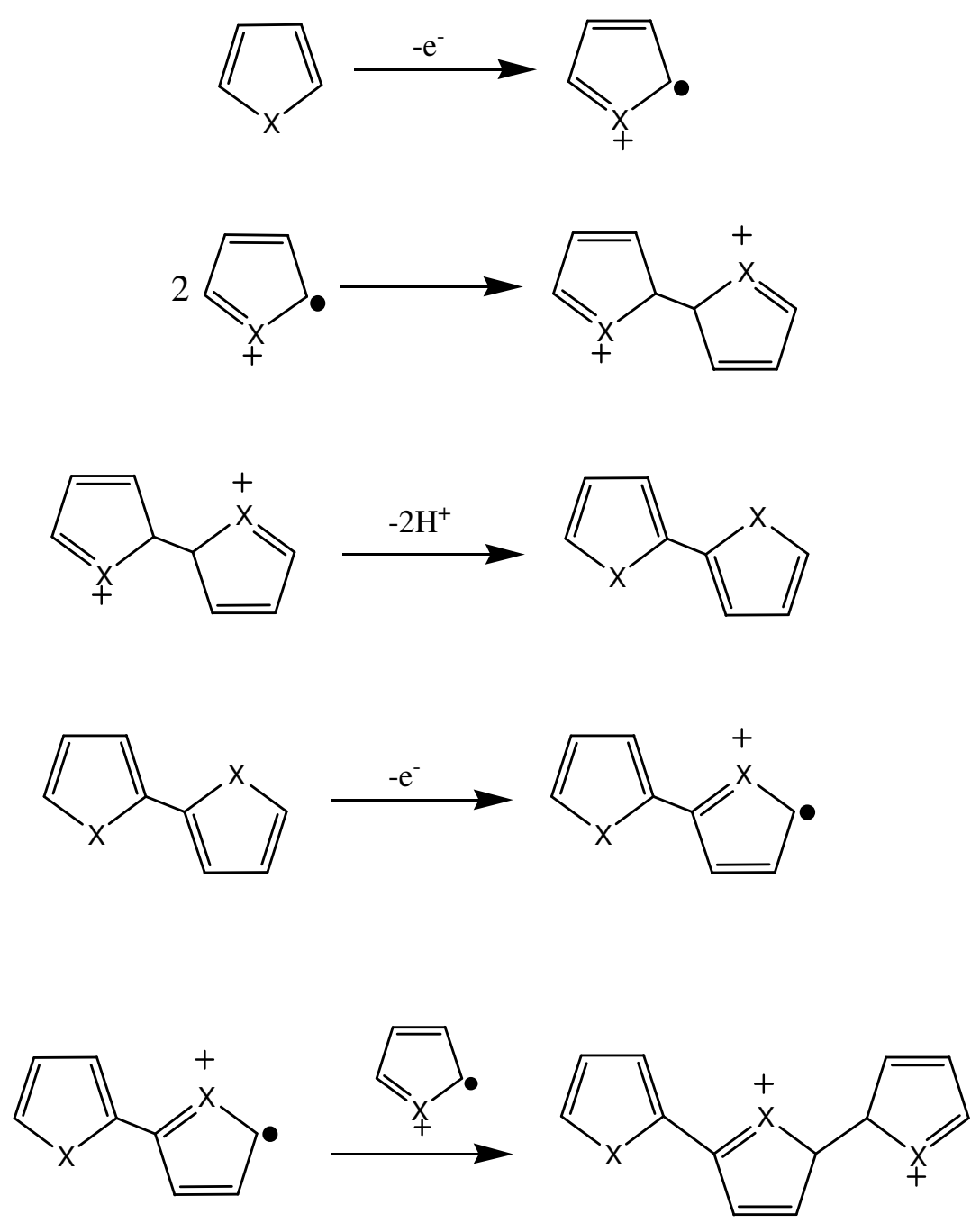

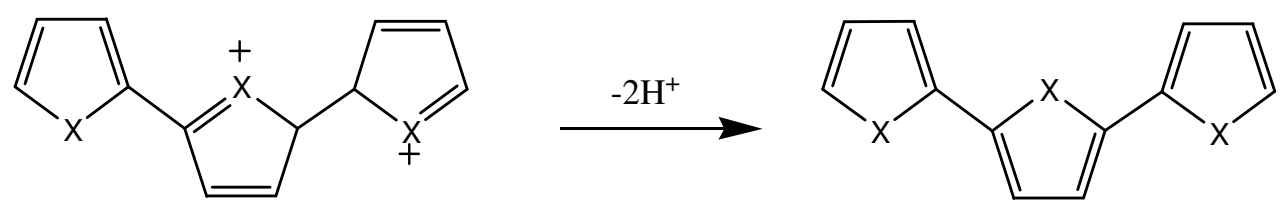

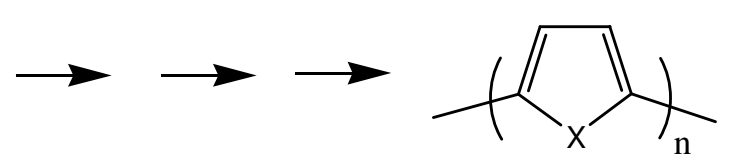

Figure 1.6 Proposed mechanism for the electrochemical polymerization of five membered heterocyclic monomers ( $\mathrm{X}=\mathrm{NH}, \mathrm{S}, \mathrm{O}$ ) 


\subsubsection{Applications of Conducting Polymers}

In the last two decades, the potential applications for conjugated polymers were thought to be their use as plastic-metals. More recently, conducting polymers have been used for many applications due to their chemical, mechanical, optical and electrical properties. As electronic materials, the use of л-conjugated polymers was enhanced after the invention of conducting polymers. Their semiconductor properties allow conjugated polymers to be used particularly in large area, such as eletrochromic devices (EDC's) [27-29], rechargeable batteries [30], light emitting diodes (LED's) [31,32], field effective transistors (FET's) [33], photovoltaic cells[34] and chemical sensors $[35,36]$.

\subsection{Enzymes}

\subsubsection{General Information for Enzymes}

The early development of the concept of catalysis in the $19^{\text {th }}$ century, went hand in hand with the discovery of powerful catalysts from biological sources. Enzymes are biological catalysts. They increase the rate of chemical reactions taking place within the living cells without themselves suffering any overall change.

Enzymes have a number of distinct advantages over conventional chemical catalysts. Foremost among these are their specificity and selectivity not only for particular reactions but also in their discrimination between similar parts of molecules or optical isomers. They catalyze only the reactions of very narrow ranges of reactants. The reactant of enzyme catalyzed reactions is termed substrates and each enzyme is quite specific in character, acting on a particular substrate or substrates to produce o particular product or products.

Enzymes are proteins. However, without the presence of non-protein component called cofactor, many enzyme proteins lack catalytic activity. When this is the case, the inactive protein component of an enzyme is termed the apoenzyme, and the active enzyme, including cofactor, the holoenzyme. The cofactor may be an 
organic molecule, when it is known as a coenzyme or it may be a metal ion. Some enzymes bind cofactors more tightly than others. When a cofactor is bound tightly (that it is difficult to remove without damaging the enzyme) it is sometimes called a prosthetic group [37].

An enzyme can be a large protein made up of several hundred amino acids, or several proteins that act together as a unit. Proteins consist of amino acids linked by peptide bonds. Peptide bonds are bonds made from a condensation reaction that bonds a carboxyl carbon of one molecule with the nitrogen of an amino group of another molecule [38,39]. Basic structure of an enzyme and formation of a peptide bond are shown in Figure 1.7.

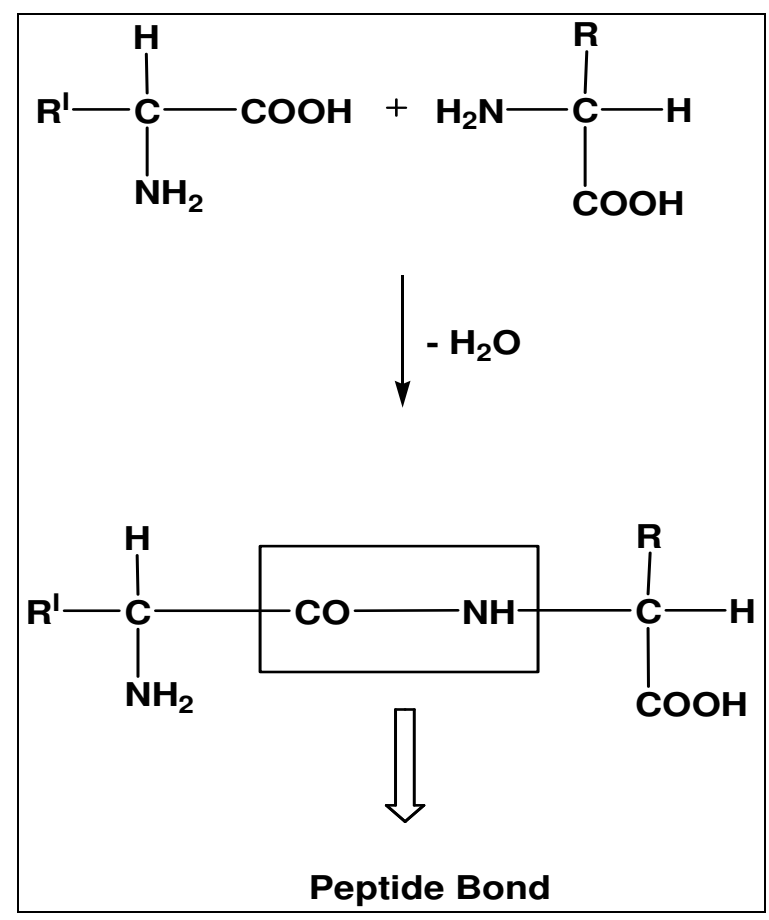

Figure 1.7 Structural representation of a basic enzyme molecule and polypeptide bond formation.

Some of the earliest studies on catalysts were done by the Swedish chemist Jöns Jakob Berzelius in 1835. Even though the catalytic activity of enzymes found in 
yeast (the word enzyme stands for "in yeast" in ancient Greek) had been used for centuries, it was not until 1926 that the first enzyme was obtained in pure form (crystalline). This was done by James B. Sumner of Cornell University. He later (1946) received the Nobel Prize for his work on the enzyme urease, extracted from jack bean .

\subsubsection{Classification of Enzymes}

By common convention, an enzyme's name consists of a description of what it does, with the word ending in "-ase". The International Union of Biochemistry and Molecular Biology has developed a nomenclature for enzymes, the enzyme commission (EC) numbers. The Enzyme Commission divided enzymes into six main classes, on the basis of total reaction catalyzed. Each enzyme is described by a sequence of four numbers, preceded by EC. The first number broadly classifies the enzyme based on its reaction mechanism.

1. Oxidoreductases: catalyze oxidation/reduction reactions.

2. Transferases: transfer a functional group (e.g. a methyl of phosphate group).

3. Hydrolases: catalyze the hydrolysis of various bonds.

4. Lyases: cleave various bonds by means other than hydrolysis and oxidation.

5. Isomerases: catalyze isomerization changes within a single molecule.

6. Ligases: join two molecules with covalent bonds.

\subsubsection{Enzyme Kinetics}

Enzymes increase the reaction rate by favoring or enabling a different pathway with lower activation energy, making easier for the reaction to occur. The overall rate of enzyme mediated reactions depends on many factors. Heat, $\mathrm{pH}$ and 
cofactors are controlling factors of enzyme activity. Enzymes can perform up to several million catalytic reactions per second. The free energy of the reaction is not changed by the presence of the enzyme, but for a favored reaction, the enzyme can speed it up, that shown in Figure 1.8.

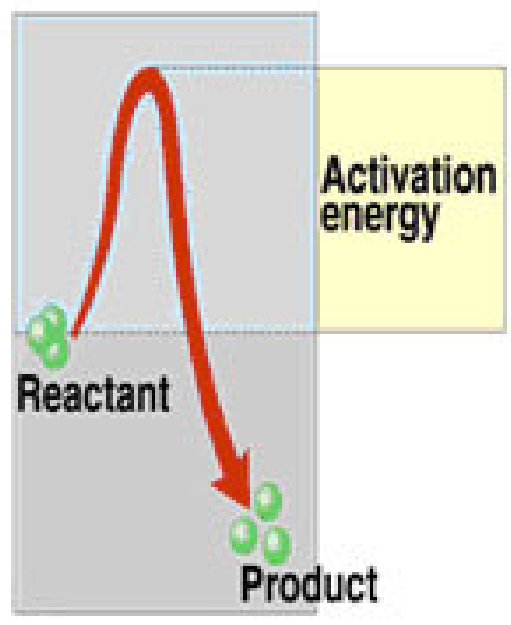

(a)

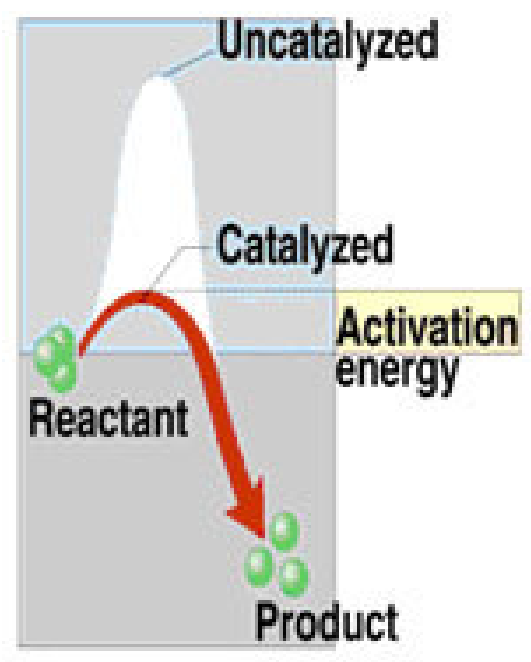

(b)

Figure 1.8 Activation energy diagram of enzyme catalyzed reaction.

Enzymes have affinity for the substrate in a transition state. They get the substrate into the right conformation which will lead to the breakdown into the products. The part of the enzyme that does work is called the active site. Each enzyme binds with a specific substrate at the enzyme's active site. The residue in this site is the right $3 \mathrm{D}$ conformation to accomplish the enzyme's work. This work is explained by the key-lock model (Figure 1.9). 


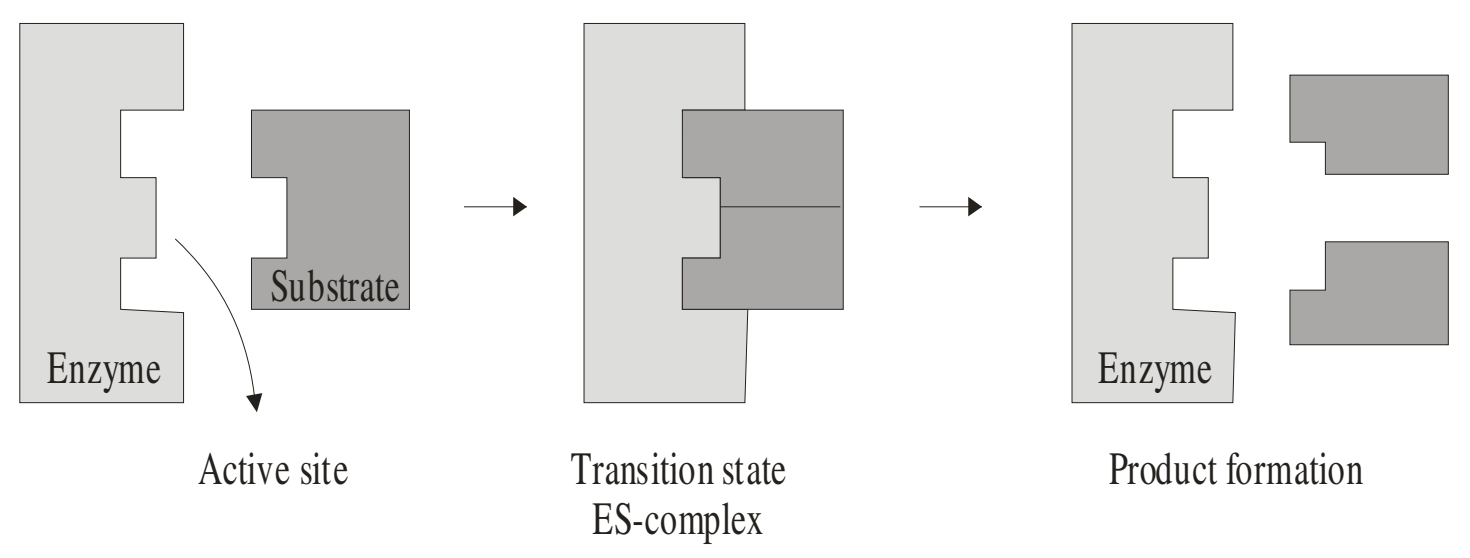

Figure 1.9 Schematic representation of "key-lock" model.

To determine the kinetics of enzymatic reactions in 1913 Leonor Michaelis and Maud Menten proposed a scheme for the enzyme catalyzed reaction involving single enzyme and single substrate system [41]. E is the free enzyme, $\mathrm{S}$ is the substrate, ES is the enzyme-substrate complex and $\mathrm{P}$ is the reaction product where $\mathrm{k}_{+1}, \mathrm{k}_{-1}$ and $\mathrm{k}_{+2}$ are the respective rate constants (Eqn 1.1).

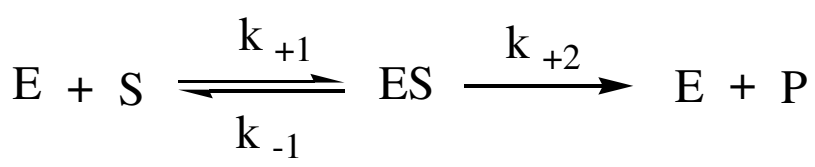

At the beginning of reaction when there is no product present or when the reaction is irreversible, the rate of reaction $(\mathrm{V})$ is the rate at which the product is formed.

$$
\mathrm{V}=\frac{\mathrm{d}[\mathrm{P}]}{\mathrm{dt}}=\mathrm{k}_{+2}[\mathrm{ES}]
$$


where "[]" indicates the molar concentration of the material. The rate of concentration change of enzyme-substrate complex equals to the rate of enzyme-substrate formation minus the rate of forward reaction to the formation of product or backwards reaction to the regeneration of substrate. Then:

$$
\frac{\mathrm{d}[\mathrm{ES}]}{\mathrm{dt}}=\mathrm{k}_{+1}[\mathrm{E}][\mathrm{S}]-\left(\mathrm{k}_{-1}+\mathrm{k}_{+2}\right)[\mathrm{ES}]
$$

During the reaction, the total enzyme at the beginning is present as free enzyme or the enzyme-substrate complex.

$$
[\mathrm{E}]_{\mathrm{o}}=[\mathrm{E}]+[\mathrm{ES}]
$$

then:

$$
\frac{\mathrm{d}[\mathrm{ES}]}{\mathrm{dt}}=\mathrm{k}_{+1}\left([\mathrm{E}]_{\mathrm{o}}-[\mathrm{ES}]\right)[\mathrm{S}]-\left(\mathrm{k}_{-1}+\mathrm{k}_{+2}\right)[\mathrm{ES}]
$$

After arrangement of terms:

$$
\begin{aligned}
& \frac{\mathrm{d}[\mathrm{ES}]}{\mathrm{dt}}=\mathrm{k}_{+1}[\mathrm{E}]_{\mathrm{o}}[\mathrm{S}]-\mathrm{k}_{+1}[\mathrm{ES}][\mathrm{S}]-\left(\mathrm{k}_{-1}+\mathrm{k}_{+2}\right)[\mathrm{ES}] \\
& \frac{\mathrm{d}[\mathrm{ES}]}{\mathrm{dt}}=\mathrm{k}_{+1}[\mathrm{E}]_{\mathrm{o}}[\mathrm{S}]-\left(\mathrm{k}_{+1}[\mathrm{~S}]+\mathrm{k}_{-1}+\mathrm{k}_{+2}\right)[\mathrm{ES}]
\end{aligned}
$$




$$
\frac{\frac{\mathrm{d}[\mathrm{ES}]}{\mathrm{dt}}}{\mathrm{k}_{+1}[\mathrm{~S}]+\mathrm{k}_{-1}+\mathrm{k}_{+2}}+[\mathrm{ES}]=\frac{\mathrm{k}_{+1}[\mathrm{E}]_{\mathrm{o}}[\mathrm{S}]}{\mathrm{k}_{+1}[\mathrm{~S}]+\mathrm{k}_{-1}+\mathrm{k}_{+2}}
$$

In equation 1.6, it can be assumed that the left hand side is only equal to [ES]. This assumption is valid under steady state approximation where the formation rate of ES equals to its disappearance rate by the formation of product and reversion of substrate.

$$
\frac{\mathrm{d}[\mathrm{ES}]}{\mathrm{dt}}=0
$$

when:

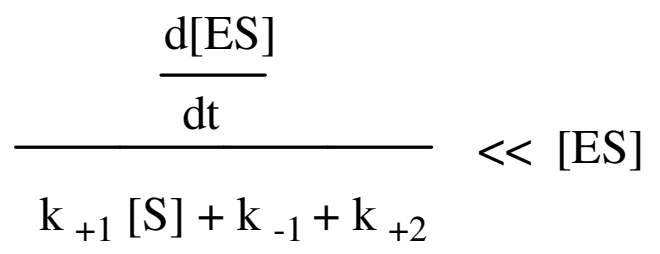

To determine the maximum speed of an enzymatic reaction, the substrate concentration is increased until a constant rate of product formation is achieved. This is the maximum velocity $\left(\mathrm{V}_{\max }\right)$ of the enzyme. In this state, all enzyme active sites are saturated with substrate. Since the substrate concentration at $\mathrm{V}_{\max }$ cannot be measured exactly, enzymes are characterized by the substrate concentration at which the rate of reaction is half its maximum. This substrate concentration is called the MichaelisMenten constant $\left(\mathrm{K}_{\mathrm{M}}\right)$. The Michaelis-Menten equation is derived from equations 1.2 and 1.6, by substituting $\mathrm{K}_{\mathrm{M}}$ for: 


$$
\mathrm{K}_{\mathrm{M}}=\frac{\mathrm{k}_{-1}+\mathrm{k}_{+2}}{\mathrm{k}_{+1}}
$$

$\mathrm{K}_{\mathrm{M}}$ is in the range $10^{-1}-10^{-5}$ in general. When $\mathrm{k}_{+2} \ll \mathrm{k}_{-1}, \mathrm{~K}_{\mathrm{M}}$ equals to the dissociation constant $\left(\mathrm{k}_{-1} / \mathrm{k}_{+1}\right)$ of enzyme-substrate complex.

$$
\mathrm{V}=\mathrm{k}_{+2}[\mathrm{ES}]=\frac{\mathrm{k}_{+2}[\mathrm{E}]_{\mathrm{o}}[\mathrm{S}]}{[\mathrm{S}]+\mathrm{K}_{\mathrm{M}}}
$$

and then:

$$
\mathrm{V}=\frac{\mathrm{V}_{\max }[\mathrm{S}]}{[\mathrm{S}]+\mathrm{K}_{\mathrm{M}}}
$$

Equation 1.10 may be arranged to another expression to show the dependence of the reaction rate on the ratio of $[\mathrm{S}]$ to $\mathrm{K}_{\mathrm{M}}$ :

$$
\mathrm{V}=\frac{\mathrm{V}_{\max }}{1+\frac{\mathrm{K}_{\mathrm{M}}}{[\mathrm{S}]}}
$$

and final form of Michaelis-Menten equation equals to: 


$$
\mathrm{V}=\frac{\mathrm{V}_{\max }[\mathrm{S}]}{[\mathrm{S}]+\mathrm{K}_{\mathrm{M}}}
$$

A graph of $\mathrm{V}$ versus [S] has the form of hyperbola. $\mathrm{K}_{\mathrm{M}}$ can also be obtained from the graph. Therefore, $\mathrm{K}_{\mathrm{M}}$ is the value of $[\mathrm{S}]$ which gives an initial velocity equal to $1 / 2 \mathrm{~V}_{\max }$ (Figure 1.10). Lineweaver-Burk plot obeys the Michaelis-Menten equation [42].

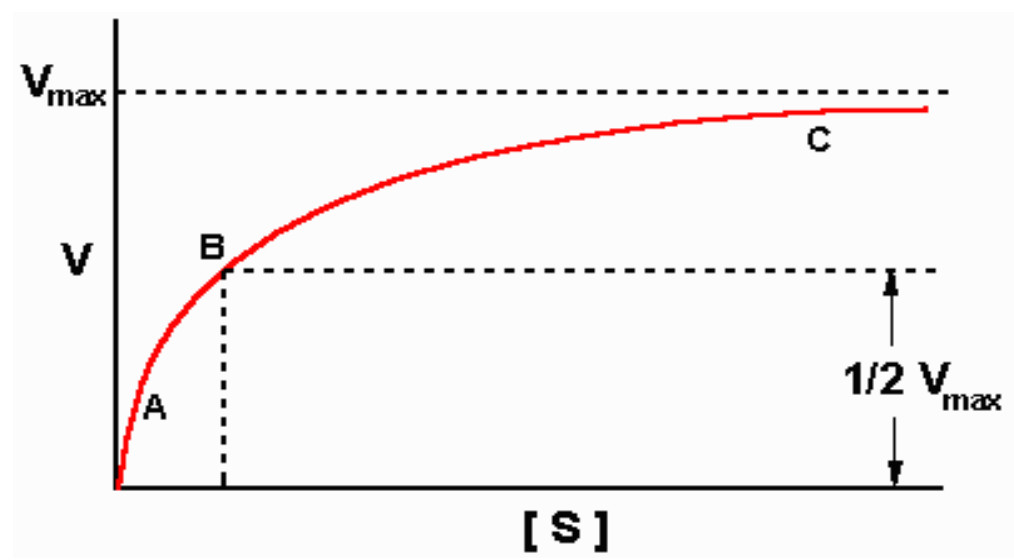

Figure 1.10 Reaction velocity vs. substrate concentration.

Lineweaver-Burk plot obeys the Michaelis-Menten equation [42]. It is given in Figure 1.11. The plot of $1 / \mathrm{V}$ versus $1 /[\mathrm{S}]$ (Lineweaver-Burk plot) gives a straight line that has a slope $\mathrm{K}_{\mathrm{M}} / \mathrm{V}_{\max }$ and intercept of $1 / \mathrm{V}_{\max }$. 


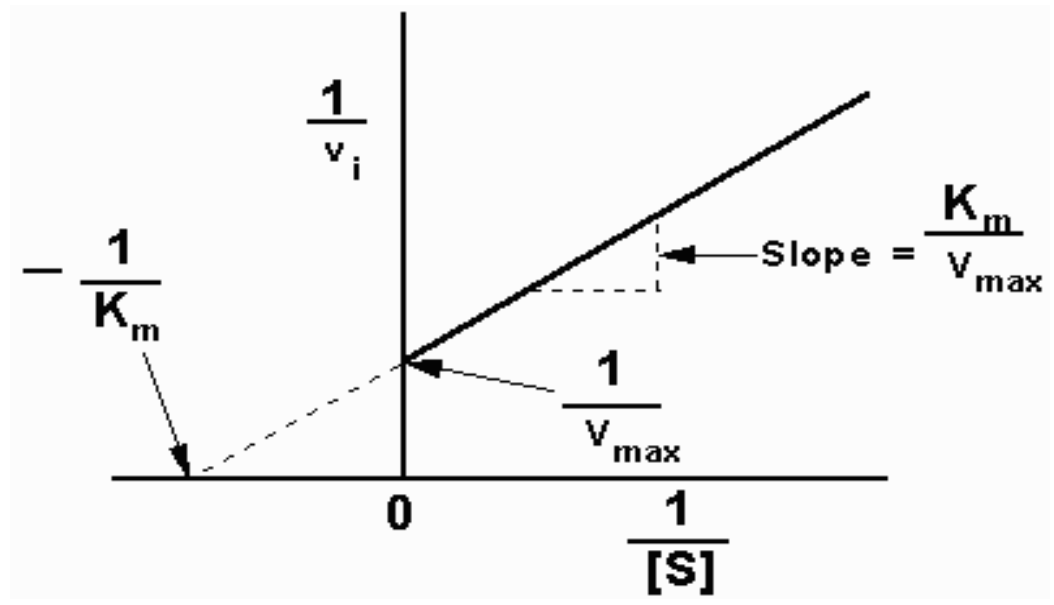

Figure 1.11 Lineweaver-Burk plot.

\subsubsection{Immobilization of Enzymes}

An important factor determining the use of enzymes in a technological process is their cost. The easiest way for separation of the enzyme from product during the reaction consists of two-phases; one phase containing the enzyme and the other phase containing the product. This is known as immobilization. This may be achieved by fixing the enzyme to some other material [43-45]. A wide variety of insoluble materials may be used to immobilize the enzymes. These are usually inert polymeric or inorganic matrices [46,47].

\subsubsection{Advantages}

The main advantages of immobilized enzymes are:

- Easy separation from reaction mixture, providing the ability to control reaction times and minimize the enzyme lost in the product.

- Multiple or repetitive use of enzymes for many reaction cycles, lowering the total production cost of enzyme catalyzed reactions. 
- Ability of enzymes to replace multiple chemical steps and provide pure products.

- Stability and activity control to prevent denaturation of enzyme in the reaction medium.

\subsubsection{Immobilization Types}

Immobilized enzymes have been defined as enzymes that are physically localized with retention of their catalytic activity, and can be used continuously. In enzyme immobilization it is very important to select the method of binding that will not cause loss of enzyme activity by changing the chemical nature or active site of the enzyme. It is important to avoid binding of the active sites of enzyme hence, active site can be protected during immobilization process as long as it is needed.

There are a variety of methods by which enzymes can be localized, ranging from covalent chemical bonding to physical entrapment, however, they can be broadly classified as follows [48-50]:

1. Covalent bonding of enzyme to a matrix.

2. Adsorption of enzyme onto a matrix.

3. Intermolecular crosslinking of enzyme using multifunctional reagents.

4. Entrapment of enzyme inside a lattice or semipermeable membrane.

\subsection{Covalent Bonding}

The most studied and the oldest immobilization technique is the formation of covalent bonds between the enzyme and support matrix (Figure 1.12). 


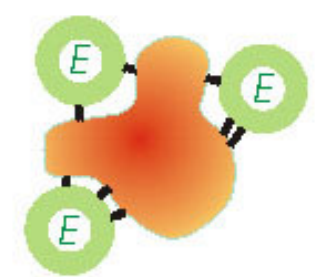

\section{E Enzyme molecule}

Solid or porous support

Figure 1.12 Illustration of covalent bonding method.

The covalent bonding method is based on the binding of enzymes and water-insoluble carriers by covalent bonds. The bond is formed between functional groups present on the surface of the support and functional groups that belong to amino acid residues on the enzyme surface. The functional groups that may take part in this bond formation are: Amino, Carboxyl, Hydroxyl, Sulfhydryl, Imidazole, Phenolic, Thiol, Threonine and Indole groups. In covalent bonding two points are important: the binding reaction must be performed under conditions that do not cause activity loss and the active site of enzyme must not be affected from the reagents used in the reaction. Crosslinking provides stability to enzymes into the surrounding solution.

\subsection{Adsorption}

Adsorption technique is the simplest immobilization method. This method is based on the physical adsorption of enzyme on the surface of water insoluble carriers (Figure 1.13). 


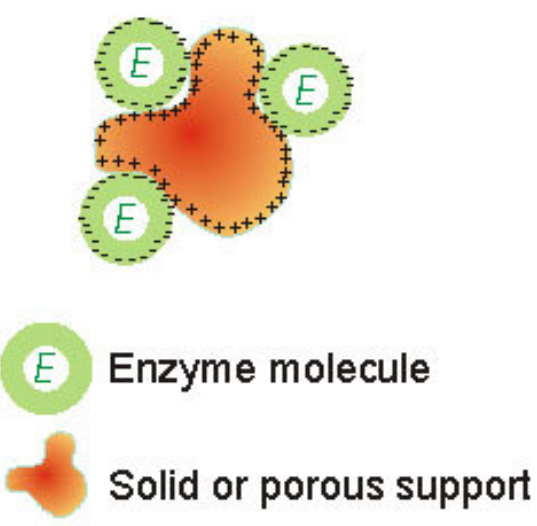

Figure 1.13 Illustration of adsorption method.

It depends on mostly electrostatic forces as Van der Waals, ionic and hydrogen bond interactions. Adjustments can be done by changing $\mathrm{pH}$, temperature, ionic strength parameters. If a suitable carrier is found, this method is simple and very cheap. The major advantage of this method is no chemical reagent or activation step are required.

\subsection{Intermolecular Crosslinking}

Intermolecular crosslinking is a support-free technique. This method is based on the crosslinking of enzyme to each other to form a 3D structure (Figure 1.14).

Intermolecular crosslinking can be achieved by crosslinking of proteins to other proteins or functional groups of different molecules such as glutaraldehyde. This method is rarely used because it is expensive, insufficient method and has poor mechanical properties. 


\section{$E \backslash E)(E) E(E$}

E Enzyme molecule

Figure 1.14 Illustration of intermolecular crosslinking method.

\subsection{Entrapment}

Entrapment of enzyme based on the fixing of enzyme inside a lattice or semipermeable membrane (Figure 1.15).
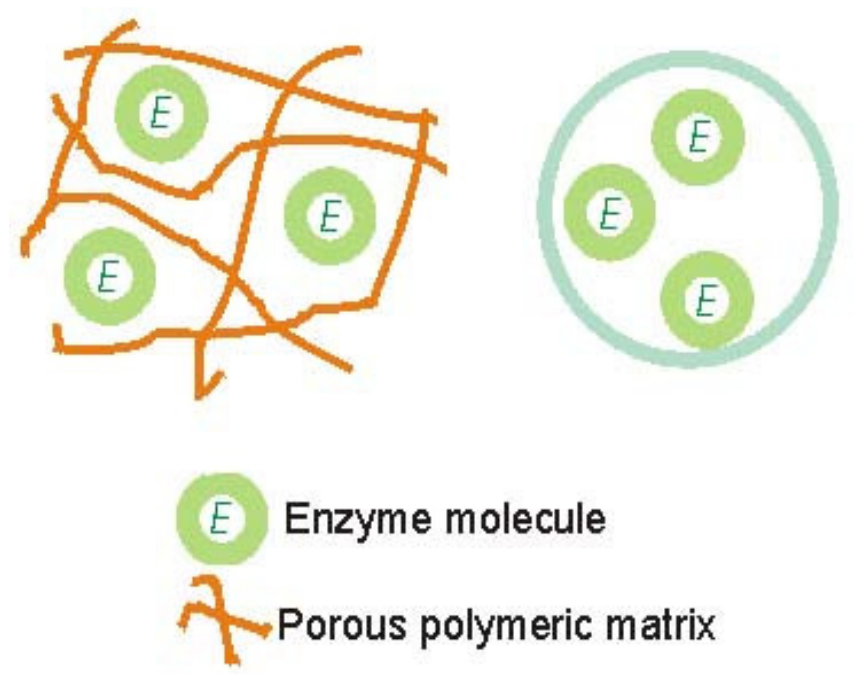

Semipermeable membrane

Figure 1.15 Illustration of entrapment method.

Entrapment is different from adsorption or crosslinking in the sense that enzyme does not directly bind to the matrix or other enzyme molecules. Enzyme 
molecules are free in solution, but entrapped by lattice or membrane. It can be achieved by using ionic interactions of enzyme and lattice structure. The solid supports used for this method can be polymeric, inorganic or organic.

\subsubsection{Immobilization by Electropolymerization}

Since the pioneering work of Foulds and Lowe [51,52], the immobilization of enzymes in an electropolymerized polymer film has proven to be a well suited immobilization method for biosensor construction. The enzyme is usually bulkentrapped in a polymer matrix which grows onto the electrode surface from the solution containing dissolved monomer and enzyme.

The monomer is electrochemically oxidized at a polymerization potential giving rise to free radicals. These radicals are adsorbed onto the electrode surface and undergo a wide variety of reactions leading to the polymer network. The growth of this polymer depends on its electrical character. The growth of conductive polymers is virtually unlimited. The process is governed by the electrode potential and by the reaction time, allowing the control of the thickness of the film. Polymerization occurs on the electrode surface and the enzyme is entrapped in the growing chain. In addition, combination of different conducting and non-conducting polymers allows the building of multilayer structures with extremely low thickness to get fast responding sensors with reduced interferences. The film can be generated by cycling the potential (potentiodynamic) or at a fixed potential (potentiostatic).

Immobilization of enzymes by electropolymerization method has several advantages over other methods. It is an easy, one-step procedure and effective. It enables the control of film thickness exactly and high quality films can be obtained by this method. Also, the amount of enzyme required for this process is very low. 


\subsubsection{Applications of Immobilized Enzymes}

Immobilized enzymes may find potential use in wide variety of applications, including food industry, chemical analysis, pharmaceutical production and medical applications, waste water treatment, etc. Research in this area is focused upon the development of stable immobilized enzyme preparations and the design of them to industrial applications.

Many of the most useful applications of immobilized enzymes are in the food industry. They are used to produce or process foodstuffs. Their action is complicated due to the effect that small amount of by-products or associated reaction products have such subjective effects as smell, taste and color. The most important application of immobilized enzymes in industry is the use of glucose isomerase in glucose syrup conversion [53]. Historically, invertase is perhaps the first reported enzyme in an immobilized form [54]. One of the major applications of immobilized enzyme in dairy industry is in the preparation of lactose-hydrolyzed milk by using $\beta$ galactosidase.

A very large number of enzymes find use in pharmaceutical industry and medical applications. One of the major applications of immobilized enzymes in pharmaceutical industry is the production of 6-aminopenicillanic acid by utilizing penicillin acylase [55]. Immobilized oxidoreductases are gaining considerable importance in carrying out synthetic transformations such as asymmetric synthesis of amino acids, steroids and other pharmaceuticals. They play a major role in clinical diagnosis and biosensor applications. At present, the most successful applications are extracellular, the removal of toxic substances and the threatment of life-threatening disorders within the blood circulation. A major potential therapeutic application of enzymes is in the treatment of cancer. Asparaginase has proved to be particularly promising for the treatment of acute lymphocytic leukaemia [56].

Another application area is the use of immobilized enzymes for chemical analysis and analytical purposes as biosensors. They are used to produce improved or novel chemicals or for use in the separation and purification of isomeric mixtures. The first industrial use in this area, is amino acid acylase [57] for the resolution of racemic mixtures of chemically synthesized amino acids. Enzyme biosensors are 
commonly used in analytical laboratories where a wide variety of analyses need to be undertaken. This is achieved by the production of biosensors such as glucose biosensor, urea biosensor for the measurement of glucose and urea levels.

\subsubsection{Tyrosinase}

Tyrosinase (EC 1.14.18.1), in other words, polyphenol oxidase (PPO), is a copper monooxygenase widely distributed in nature and is mainly involved in the formation of pigments such as melanin. The enzyme catalyzes the orthohydroxylation of monophenols (cresolase activity) and the oxidation of o-diphenols to o-quinones using molecular oxygen (Figure 1.16).<smiles>Oc1ccc(P)cc1</smiles>

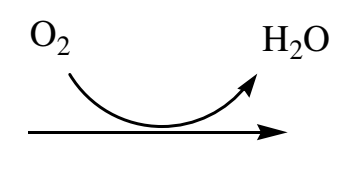

Cresolase Activity<smiles>[R]c1ccc(O)c(O)c1</smiles><smiles>[R]c1ccc(O)cc1</smiles><smiles>CC1COC1CO</smiles>

Catecholase Activity<smiles>[R]C1=CC(=O)C(=O)C=C1</smiles>

Figure 1.16 Proposed mechanism for PPO catalyzed reactions.

Early studies on the tyrosinase from the common mushroom Agaricus bisporus suggested that enzyme possesses a molecular weight of 110-130 kDa and 
occurs as a tetrameric protein composed of identical subunits of $32 \mathrm{kDa}$. In 1970's, the tetrameric structure was revisited and considered as two subunits of $43 \mathrm{kDa}$ and two subunits of $13 \mathrm{kDa}$ [58-60]. The quaternary structure was assumed with a native molecular weight of approximately $110 \mathrm{kDa}$ containing $4 \mathrm{Cu}$ atoms. Isoelectric point (pI) of the tyrosinase varies about 4.5 - 5.1 depending on the enzyme source. In the case of tyrosinases obtained from higher plants, a rather similar story can be told. The active site of tyrosinase consists of a pair of copper ions where each are bound by three conserved histidine residues (His). This copper pair is the site of interaction of tyrosinase with both molecular oxygen and its phenolic substrates.

Mushroom is the most known source of tyrosinase in nature and other sources are some vegetables and fruits as potatoes, apples, tomatoes, bananas, some insects and bacteria. The principal substrates of tyrosinase are L-tyrosine, L-dopa, paminophenol and its condensation product with glutamate, glutaminyl-4hydroxybenzene (GHB).

Physiologically, the function of tyrosinase in plants and fungi may be protective. In higher plants, the enzyme protects the plant against insects and microorganisms by catalyzing the formation of melanin against further attack. In fruits and vegetables, tyrosinase is responsible for enzymatic browning. The mammalian enzyme is responsible for generating the melanin that is contained in surface structures such as the skin, eye, inner ear and hair. If it is either absent completely or present in a reduced amount and does not produced the normal amount of pigment, albinism disease occurs for mammalians.

Recently, tyrosinase has applications in food industry by suppressing the browning of vegetables and fruits during process.

\subsection{Phenolic Compounds}

Phenolic compounds are commonly found in both edible and non-edible plants. Bioactive phenols, especially bioflavonoids, are very interesting as antioxidants because of their natural origin and the ability to act as efficient free radical scavengers. Although phenolic compounds do not have any nutritional 
function, they have important role in human health because of their antioxidant power. The importance of the antioxidant constituents in the maintenance of health and protection from coronary disease and cancer is raising interest among scientists, food manufacturers and consumers as the trend of the future is moving toward functional food with specific health effects. The beneficial health reletad effects of certain phenols or their potential antinutritional properties, when these compounds are present in large quantities in foods, are of importance to consumers [61-63].

Phenolic compounds over 8000 are currently known [64] which have important antioxidant property in common. The major classes of phenolic compounds are flavonoids, quinines, phenolic acids, simple phenols, stilbenes, xanthones, tannins, phenylpropanoids, acetophenones, benzofurans, coumarine and chromones. Flavonoids are the major and the most abundant class of phenolic compounds.

\subsubsection{Phenolic Compounds in Tea}

Tea being an important source of phenolics, is one of the most widely consumed beverages in the world [65]. The role of tea consumption and tea based phenols (catechins) in the prevention of cancer and some other diseases have received a great deal of attention. Green and black teas have much higher antioxidant capacity than the vegetables due to their phenolic content.

Tea is generally consumed in different forms; green, oolong or black. Both green and black tea come from the leaves of the plant Camellia sinensis, however the final processing of the leaves is different. Tea is rich in phenolic compounds collectively known as the tea flavonoids. Black and green teas both contain similar amount of flavonoids however, they differ in their chemical structure. Green teas contain simple flavonoids called catechins such as epicatechin, epigallocatechin, epigallocatechingallate. After oxidation process, tea leaves produce black tea. While oxidation, simple flavonoids are converted to the more complex types called as theaflavins (Figure 1.17). Black teas contain these complex phenolic types. 
<smiles>Oc1cc(O)c2c(c1)O[C@H](c1ccc(O)c(O)c1)[C@H](O)C2</smiles>

(+)-Catechin<smiles>Oc1cc(O)c2c(c1)O[C@H](c1ccc(O)c(O)c1)[C@H](O)C2</smiles>

(-)-Epicatechin<smiles>Oc1cc(O)c2c(c1)O[C@H](c1cc(O)c(O)c(O)c1)[C@H](O)C2</smiles>

(-)-Gallocatechin<smiles>Oc1cc(O)c2c(c1)O[C@H](c1cc(O)c(O)c(O)c1)[C@H](O)C2</smiles>

(-)-Epigallocatechin<smiles>O=C(O[C@H]1Cc2c(O)cc(O)cc2O[C@H]1c1ccc(O)c(O)c1)c1cc(O)c(O)c(O)c1</smiles>

(-)-Epicatechin gallate<smiles>O=c1c(O)cc(C2Oc3cc(O)cc(O)c3C[C@H]2O)cc2c(C3Oc4cc(O)cc(O)c4C[C@H]3O)cc(O)c(O)c12</smiles>

Theaflavin

Figure 1.17 Chemical structures of green and black tea phenolics. 


\subsection{Aim of the Study}

The aim of this study is to prepare an effective tyrosinase immobilized system that can be used as a biosensor for the detection of phenolic compounds. For this purpose following steps were done.

- Electrochemical synthesis of conducting polymers and copolymers of pyrrole as enzyme carrier matrices to achieve the immobilization of tyrosinase.

- Entrapment of tyrosinase into the polypyrrole (PPy) and polydimethylsiloxane/polypyrrole (PDMS/PPy) polymer matrices efficiently.

- Determination of kinetic parameters and optimum conditions for enzyme electrodes to characterize the enzyme biosensor.

- Comparision of different supporting electrolytes to investigate the efficiency of enzyme immobilization in different supporting electrolyte media.

- Use of enzyme electrodes as a biosensor to determine phenolic compound content in black and green tea. 


\section{CHAPTER II}

\section{EXPERIMENTAL}

\subsection{Materials}

Tyrosinase (PPO) (E.C. 1.14.18.1) was purchased from Sigma and used as received without any purification. Pyrrole was purchased from Aldrich, freshly distilled before use and stored at $4^{\circ} \mathrm{C}$. Sodium dodecylsulfate (SDS) was obtained from Aldrich and p- toluene sulfonic acid (PTSA) was obtained from Sigma and used without any purification. For spectrophotometric activity determination, acetone, sulfuric acid and 3-methyl-2-benzothiazolinone hydrazone (MBTH), were purchased from Sigma. For the preparation of citrate buffer, citric acid and tri-sodium citrate-2 hydrate were used. Catechol was obtained form Sigma and used as received.

The insulating polymer, pyrrole functionalized polydimethylsiloxane (PDMS), was synthesized at The Chemistry Department of Istanbul Technical University, Turkey $[69,70]$.

\subsection{Instrumentation}

\subsubsection{Potentiostat}

A potentioscan Wenking POS-73 model potentiostat was used for electropolymerization of films at constant potential. This potentiostat supply fixed 
voltage during the electrolysis by keeping the voltage difference between the working and reference electrodes at a constant value.

\subsubsection{Electrolysis Cell}

Constant potential electrolysis (Potentiostatic) was performed in a typical three electrode system which were platinum $(\mathrm{Pt})$ working and counter electrodes $(1.0$ $\mathrm{cm}^{2}$ ) and silver/silver ion $\left(\mathrm{Ag} / \mathrm{Ag}^{+}\right)$reference electrode. The electrochemical synthesis was carried out in electrolysis cell that can contain $10 \mathrm{ml}$ solution (Figure 2.1). Constant potential electrolysis method was applied. The film thickness can be controlled by the adjustment of the polymerization time.

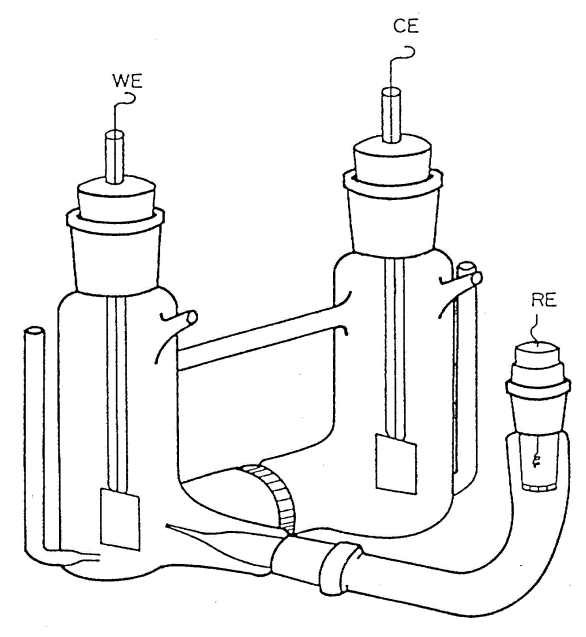

Figure 2.1 Electrolysis cell.

\subsubsection{UV-Visible Spectrophotometer}

A Shimadzu UV-1601 model spectrophotometer was used for the activity determination of both free and immobilized enzyme. 


\subsubsection{Scanning Electron Microscope (SEM)}

Surface analysis of films was done by using JEOL JSM-6400 scanning electron microscope.

\subsection{Experimental Procedure}

\subsubsection{Immobilization of Tyrosinase in Conducting Copolymers of Polydimethylsiloxane (PDMS)}

Immobilization of tyrosinase (PPO) in PDMS/PPy copolymer matrice (Figure 2.2) was performed in a typical three electrode cell. Different enzyme electrodes PDMS/PPy/SDS, PPy/SDS, PDMS/PPy/PTSA and PPy/PTSA were prepared in different electrolysis conditions. The electrolyses were carried out by applying a constant potential of $+1.0 \mathrm{~V}$ at room temperature for 20 min except for PDMS/PPy/PTSA enzyme electrode which was prepared in 45 min. Immobilization of PPO was achieved either on bare or previously PDMS coated platinum (Pt) electrode. For the preparation of enzyme electrodes PDMS/PPy/SDS and PPy/SDS, electrolysis solution consists of $0.15 \mathrm{mg} / \mathrm{ml}$ PPO, $2.0 \mathrm{mg} / \mathrm{ml} \mathrm{SDS}$ as the supporting electrolyte, $0.115 \mathrm{M}$ pyrrole and citrate buffer ( $\mathrm{pH}$ 6.5). PDMS/PPy/PTSA and PPy/PTSA enzyme electrodes were prepared in an electrolysis cell containing 0.15 $\mathrm{mg} / \mathrm{ml} \mathrm{PPO,} 25 \mathrm{mg} / \mathrm{ml}$ PTSA as the supporting electrolyte, $0.115 \mathrm{M}$ pyrrole and citrate buffer. High concentration of PTSA causes the denaturation of enzyme because of its acidic character. Therefore, in the case of PTSA, the pH of immobilization medium was adjusted to 6.5 by the addition of $0.1 \mathrm{M} \mathrm{NaOH}$. After electrolysis, electrodes were washed with distilled water to remove excess supporting electrolyte and unbound enzymes and kept in citrate buffer at $4{ }^{\circ} \mathrm{C}$ when not in use. 


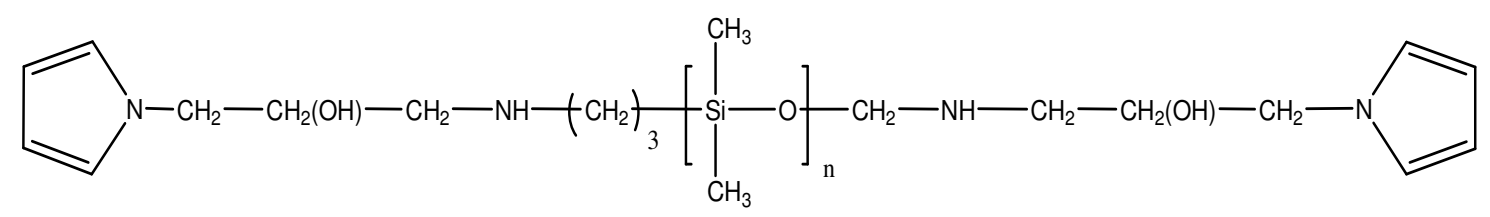

(PDMS)

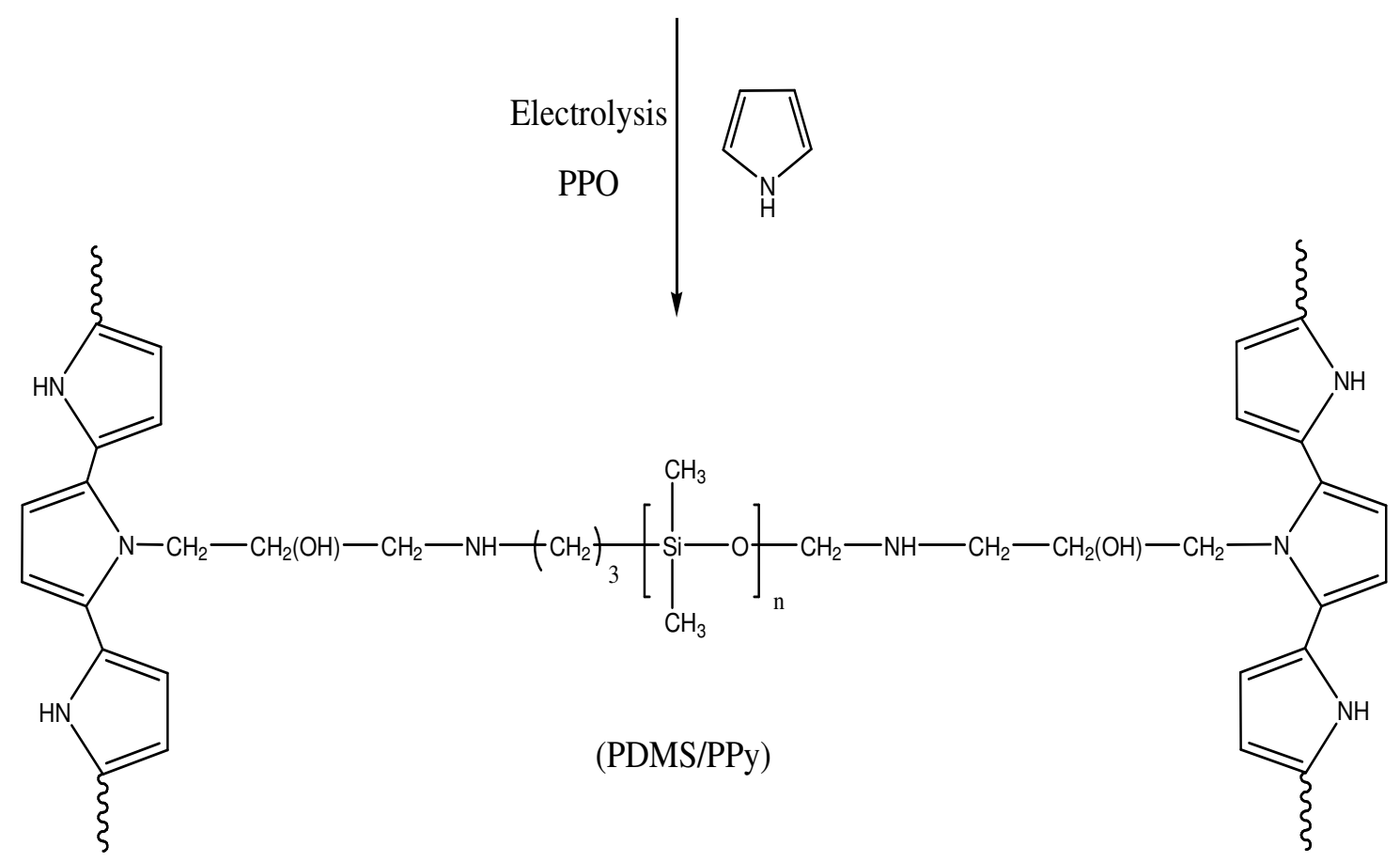

Figure 2.2 Immobilization of PPO in PDMS/PPy matrice during electrochemical polymerization.

\subsubsection{Determination of Tyrosinase Activity}

The activity determination was performed by using Besthorn's hydrazone method [71]. This method is based on the spectrophotometric measurement of the colored complex. Colored complex can be obtained from the interaction of MBTH and quinones produced by the enzymatic reaction. Proposed mechanism is given in the Figure 2.3. 


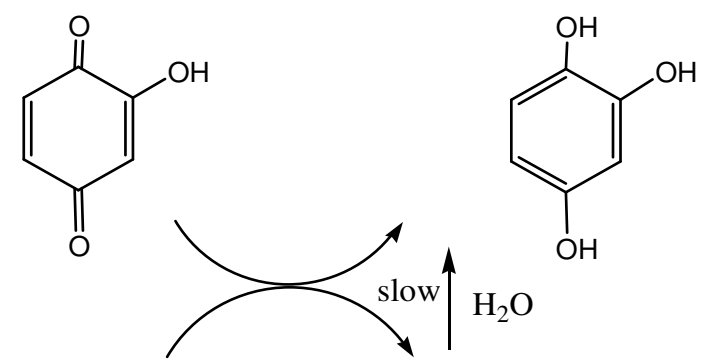

$\underset{\mathrm{O}_{2}}{\stackrel{\mathrm{E}}{\longrightarrow}}$<smiles>CC(F)(F)COc1ccccc1O</smiles><smiles>O=C1C=CC=CC1=O</smiles>

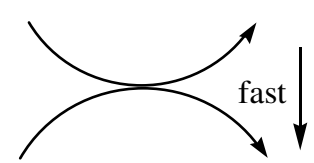<smiles>Cn1/c(=N/NC2=CC(=O)C(=O)C=C2)sc2ccccc21</smiles>

Red Pigment<smiles>Cn1/c(=N/N)sc2ccccc21</smiles>

MBTH

Figure 2.3 Schematic representation of Besthorn's Hydrazone method.

Different concentrations of catechol solutions prepared in citrate buffer $(\mathrm{pH}$ 6.5) were put in water bath at $25^{\circ} \mathrm{C} .1 .0 \mathrm{ml} \mathrm{MBTH}(0.3 \% \mathrm{w} / \mathrm{v})$ in ethanol was added to produce red complex with product and enzyme electrode was immersed into the solution. $1.0 \mathrm{ml}$ sulfuric acid solution $(5 \% \mathrm{v} / \mathrm{v})$ was added to stop the enzymatic reaction and $1.0 \mathrm{ml}$ acetone was added to dissolve the red colored complex. After mixing, absorbances were determined at $495 \mathrm{~nm}$.

\subsubsection{Determination of Kinetic Parameters}

Kinetic parameters of the PPO catalyzed reaction for both free [36] and immobilized enzyme were obtained according to the activity assay and Lineweaver- 
Burk plots. In order to determine maximum reaction rate $\left(\mathrm{V}_{\mathrm{m}}\right)$ and Michaelis-Menten constant $\left(\mathrm{K}_{\mathrm{m}}\right)$ for each electrode, activity measurement was applied for different substrate concentrations at constant assay conditions at $25^{\circ} \mathrm{C}$ and $\mathrm{pH}$ 6.5.

\subsubsection{Determination of Optimum Temperature and pH}

Optimum temperatures were determined for enzyme electrodes by changing temperature between 10 and $80^{\circ} \mathrm{C}$ while keeping the substrate concentration constant $\left(10 \mathrm{~K}_{\mathrm{m}}\right)$ at $\mathrm{pH}$ 6.5. $\mathrm{pH}$ optimization was carried out by changing the $\mathrm{pH}$ range between 2 and 11 at constant temperature $\left(25^{\circ} \mathrm{C}\right)$. Activity measurements were obtained by applying activity assay as described before.

\subsubsection{Determination of Operational Stability and Shelf-life}

Two of the most important parameters to be considered in enzyme immobilization for industrial applications are operational stability and shelf-life. Operational stabilities of enzyme electrodes were determined at optimum activity conditions ( $\mathrm{pH} 6.5,25^{\circ} \mathrm{C}, 10 \mathrm{~K}_{\mathrm{m}}$ ), by using electrodes in 40 activity assays per day. Shelf-life in terms of storage stability of electrodes was investigated by performing activity measurements at optimum conditions within 35 days.

\subsubsection{Morphologies of Films}

SEM is a surface morphology observation technique. It provides detailed information about the film surfaces and structure of the polymers. Synthesis of films was performed at optimum conditions for both free and enzyme immobilized films. Then, films were washed with buffer solution to remove unbound enzyme and supporting electrolyte. 


\subsubsection{Investigation of Phenolic Compounds in Green and Black Tea}

Two tea samples were analyzed by using enzyme electrodes for their phenolic content. Green and black tea samples (Brand N and Brand C) were prepared as substrate solutions. $25 \mathrm{mg} / \mathrm{ml}$ tea sample were stewed in distilled water for $20 \mathrm{~min}$ and filtered. Tea solutions were adjusted to $\mathrm{pH} 6.5$ and activity assay was applied at $25^{\circ} \mathrm{C}$. Phenolic contents were determined as catechin equivalents (CE) [72,73]. 


\section{CHAPTER III}

\section{RESULTS AND DISCUSSION}

\subsection{Kinetic parameters}

Kinetic parameters, Michaelis-Menten constant $\left(\mathrm{K}_{\mathrm{M}}\right)$ and maximum velocity $\left(\mathrm{V}_{\max }\right)$ of free and immobilized enzymes were investigated at constant temperature and $\mathrm{pH}$ while varying substrate concentrations. $\mathrm{K}_{\mathrm{M}}$ and $\mathrm{V}_{\max }$ were obtained from the Lineweaver-Burk plots [42]. The parameters calculated are given in Table 3.1.

\section{Table 3.1}

Kinetic parameters for free and immobilized PPO

\begin{tabular}{l|cc}
\hline & $\begin{array}{c}\mathrm{K}_{\mathrm{M}} \\
(\mathrm{mM})\end{array}$ & $\begin{array}{c}\mathrm{V}_{\max } \\
(\mu \mathrm{mol} / \text { min.electrode })\end{array}$ \\
\hline Free PPO & 4.0 & $11.2^{\mathrm{a}}$ \\
PPy/SDS/PPO & 100.0 & 0.11 \\
PDMS/PPy/SDS/PPO & 35.2 & 0.03 \\
PPy/PTSA/PPO & 205.0 & 0.12 \\
PDMS/PPy/PTSA/PPO & 182.0 & 0.10 \\
\hline
\end{tabular}

${ }^{\mathrm{a}} \mu \mathrm{mol} / \mathrm{min} . \mathrm{mg}$ protein 
The highest $V_{\max }$ value was observed for PPy/PTSA enzyme electrode and the lowest $\mathrm{K}_{\mathrm{M}}$ value was for PDMS/PPy/SDS enzyme electrode. Although different matrices were used, the maximum velocity values were in the same order except for PDMS/PPy/SDS enzyme electrode.

Free PPO has a maximum reaction rate of $11.2 \mu \mathrm{mol} / \mathrm{min} . \mathrm{mg}$ protein[36] and $\mathrm{K}_{\mathrm{M}}$ of $4 \mathrm{mM}$. The $\mathrm{V}_{\max }$ value of enzyme electrode PDMS/PPy/SDS was about 10.0 times lower than that all other enzyme electrodes. The KM values of enzyme electrodes PDMS/PPy/PTSA and PPy/PTSA were about 6.0 times higher than that PDMS/PPy/SDS electrode and about 2.0 times higher than that of PPy/SDS enzyme electrode.

The results show that there is an increase in $\mathrm{K}_{\mathrm{M}}$ values when compared with that of the free enzyme. $\mathrm{K}_{\mathrm{M}}$ parameter is directly proportional to the affinity of enzyme to substrate. Low $\mathrm{K}_{\mathrm{M}}$ values mean higher affinity. For each electrode, the increase in $K_{M}$ values is due to diffusional effects. Enzyme-substrate complex formation becomes more difficult due to presence of conducting copolymers as immobilization matrices.

The decrease in $V_{\max }$ values when compared with free enzyme is due to the difficulty of enzyme substrate interaction. $\mathrm{K}_{\mathrm{M}}$ value for PDMS/PPy/SDS matrice was comparable with that of free enzyme than other three matrices. This matrice provides suitable immobilization medium for this enzyme. Copolymerization with PPy improves the kinetic parameters such as lower $\mathrm{K}_{\mathrm{M}}$ for the electrode with SDS anion. PDMS/PPy/PTSA and PPy/PTSA matrices exhibited higher $\mathrm{K}_{\mathrm{M}}$ values and also higher activity. This means that enzyme and substrate do not prefer to come together for a long time, they leave each other immediately after product formation.

\subsection{Temperature Optimization of Enzyme Electrodes}

Temperature is one of the most important parameter for activity of enzyme electrodes. For all matrices activity increases up to a certain temperature. After the temperature that the maximum activity was observed, there is a slight decrease in activity based on the denaturation of the molecular structure and the catalytic center 
of enzyme. The effect of the reaction temperature on the activity is shown in Figure 3.1 .

(a)

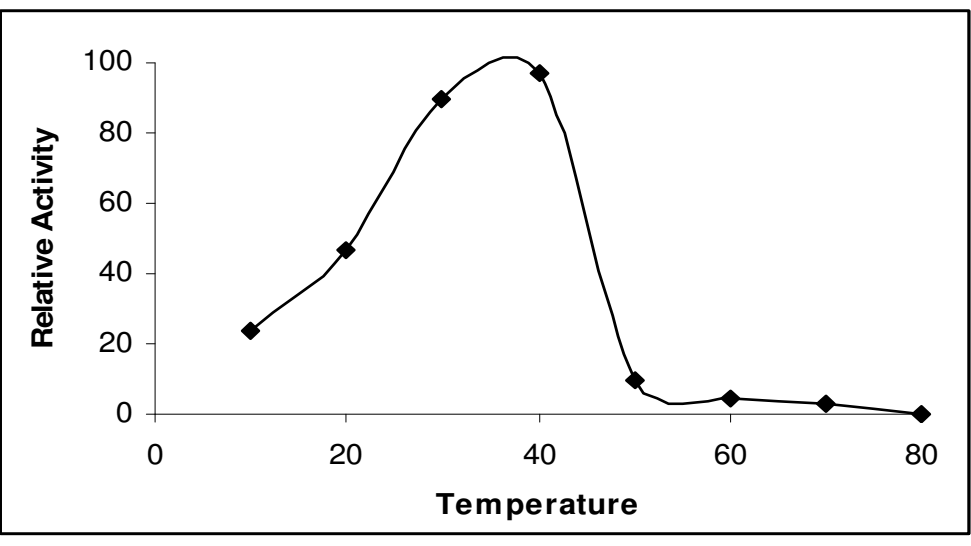

(b)

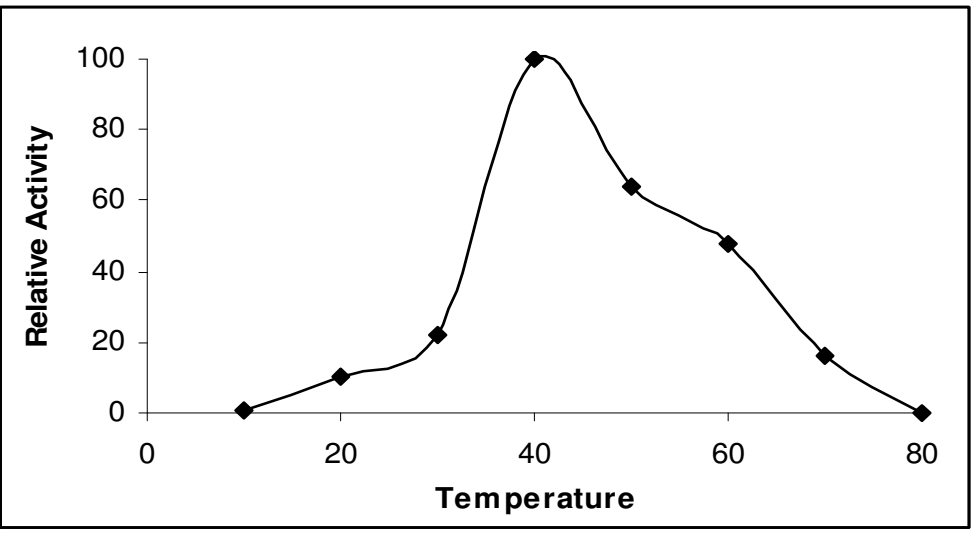

(c)

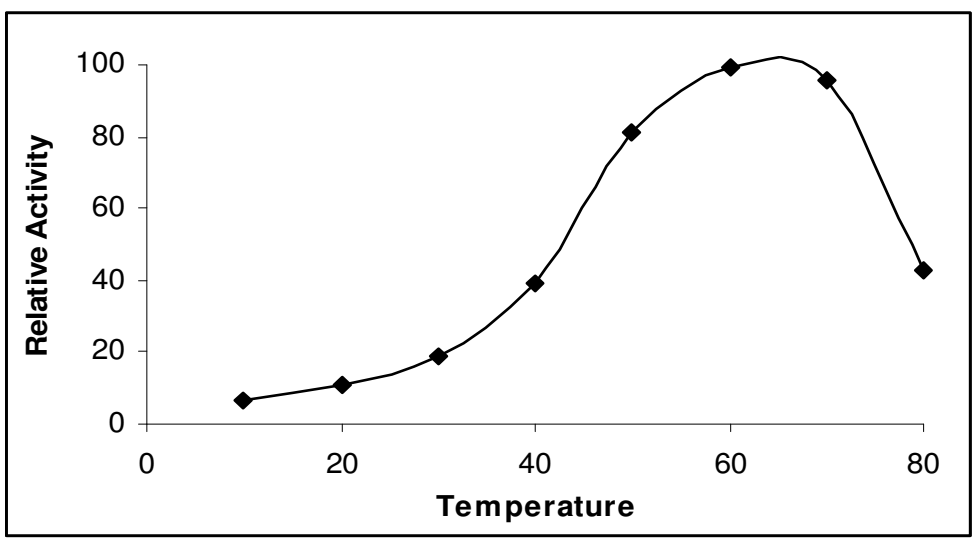


(d)

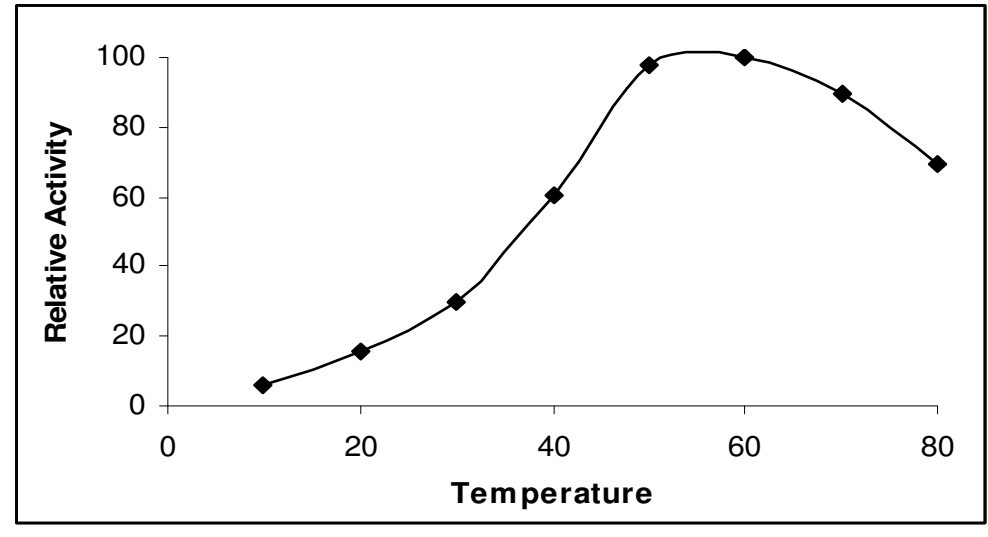

(e)

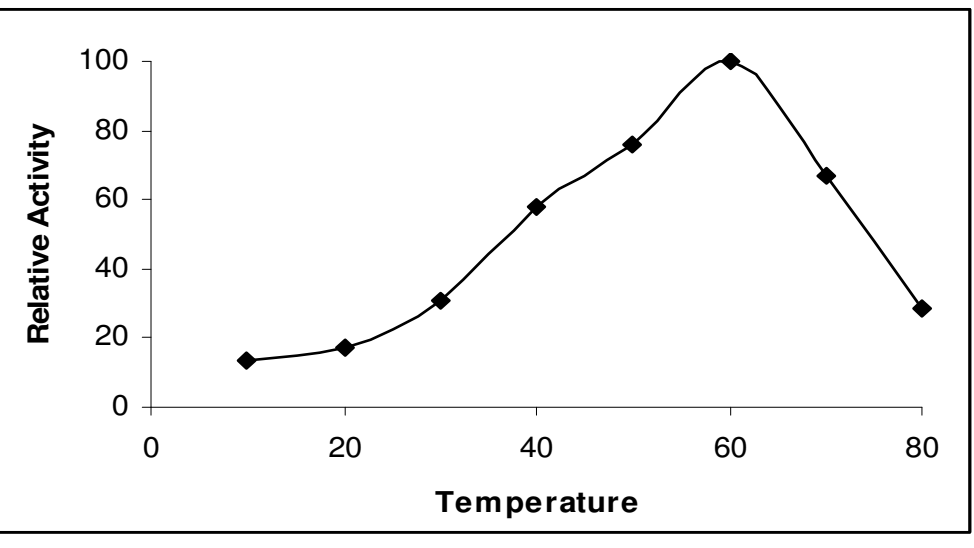

Figure 3.1 Optimum temperatures of electrodes (a) Free PPO (b) PPy/SDS/PPO (c) PDMS/PPy/SDS/PPO (d) PPy/PTSA/PPO (e) PDMS/PPy/PTSA/PPO.

Both free PPO and immobilized PPO in PPy/SDS matrice revealed a maxima at $40^{\circ} \mathrm{C}$. Free PPO lost its activity at $50^{\circ} \mathrm{C}$ completely [36] however, PPy/SDS electrode lost only $40 \%$ of its activity at that temperature. PDMS/PPy/SDS , PDMS/PPy/PTSA and PPy/PTSA electrodes showed a maxima at $60^{\circ} \mathrm{C}$. These electrodes lost their $70 \%$ of their activity at $80^{\circ} \mathrm{C}$. Denaturation occurs above $60^{\circ} \mathrm{C}$. In the presence of PTSA as the supporting electrolyte, enzyme electrodes have higher activity and resistance to high temperature. As it is mentioned before, PDMS matrice has good mechanical properties when doped with PTSA [70]. 


\section{3 pH Optimization of Enzyme Electrodes}

The variation of PPO activity with varied $\mathrm{pH}$ at optimum activity measurement conditions, was investigated for entrapped PPO in both SDS and PTSA doped PPy and PDMS/PPy matrices. The results for a $\mathrm{pH}$ range from 2 to 11 were presented in Figure 3.2.

(a)

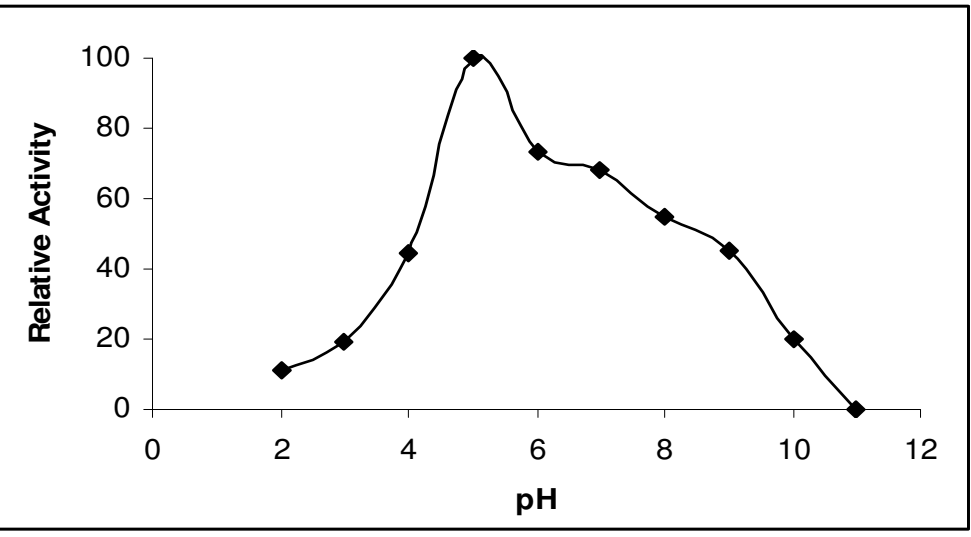

(b)

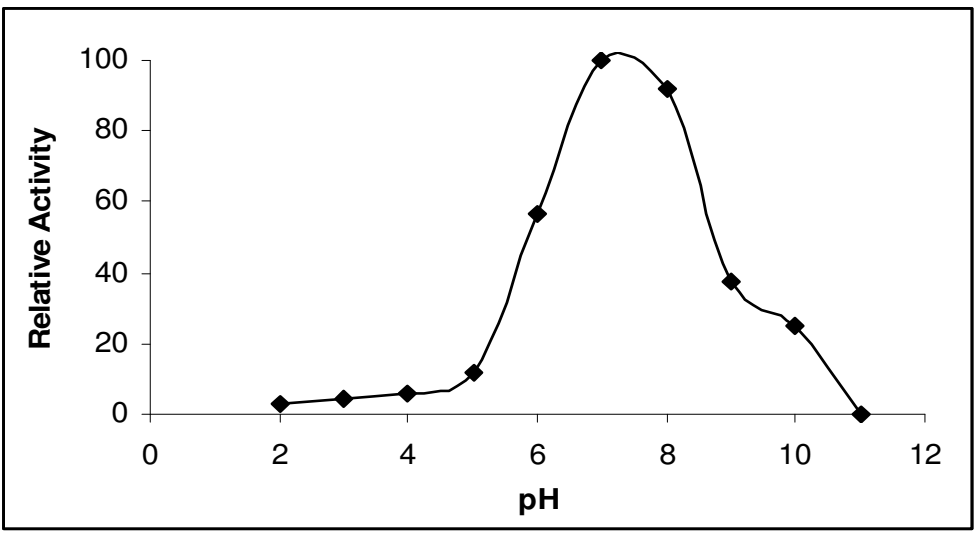


(c)

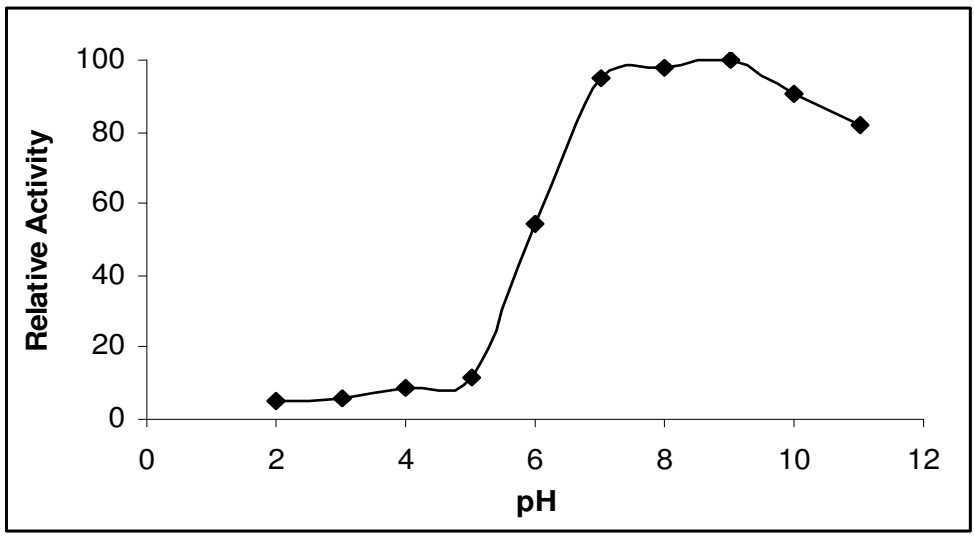

(d)

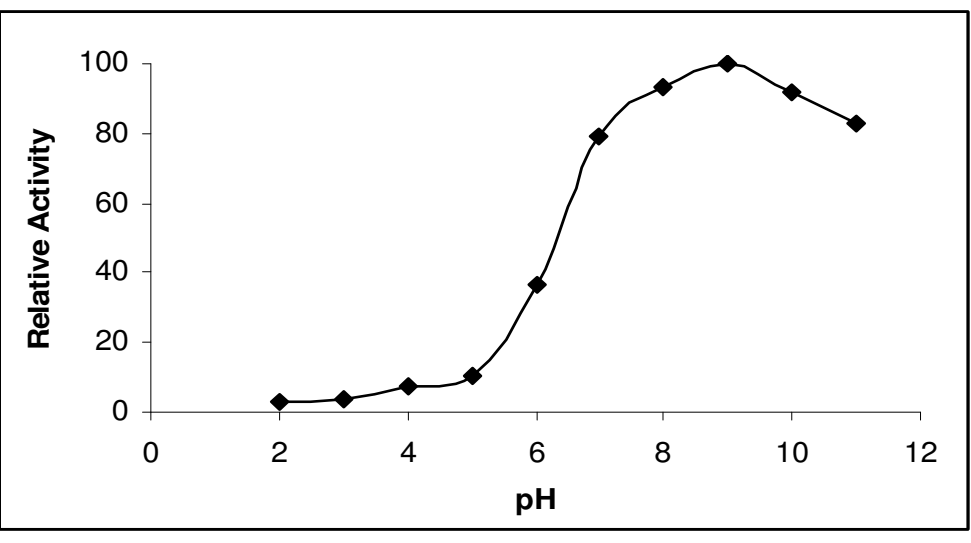

(e)

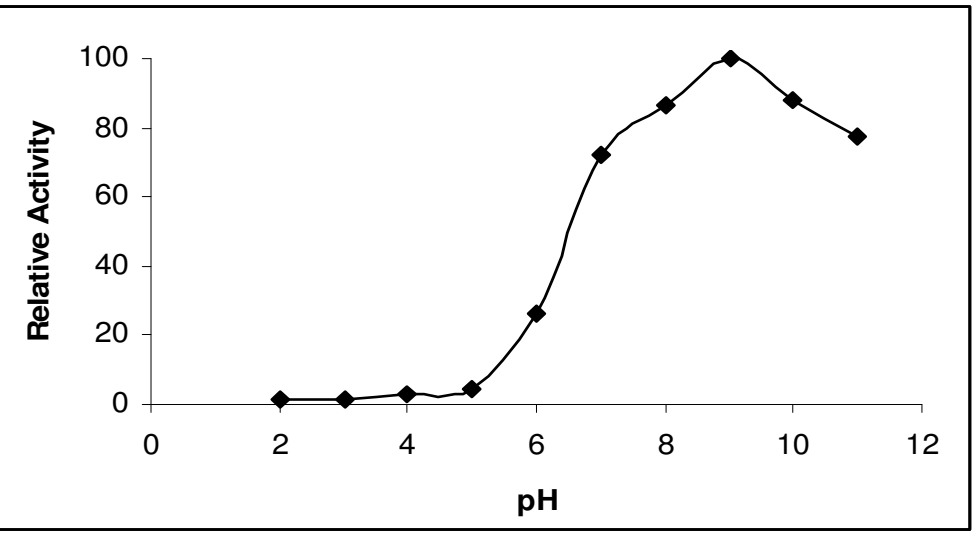

Figure 3.2 Optimum $\mathrm{pH}$ of electrodes (a) Free PPO (b) PPy/SDS/PPO (c) PDMS/PPy/SDS/PPO (d) PPy/PTSA/PPO (e) PDMS/PPy/PTSA/PPO. 
Free PPO had maximum activity at pH 5 and immobilized PPO in PPy/SDS matrice showed maximum activity at $\mathrm{pH}$ 7. PDMS/PPy/SDS , PDMS/PPy/PTSA and PPy/PTSA enzyme electrodes had a maximum activity at $\mathrm{pH}$ 9. PPy/SDS enzyme electrode lost $80 \%$ of its activity above $\mathrm{pH} 7$, whereas, other enzyme electrodes retain their activity at this $\mathrm{pH}$ value. At $\mathrm{pH}$ levels lower than 6 , the activity of enzyme electrodes were insignificant. The optimum $\mathrm{pH}$ was shifted towards the alkaline side when compared with the free enzyme. This might be explained by the partitioning of protons [74]. Protons entrapped in matrix protect the enzyme against the high concentration of $\mathrm{OH}^{-}$ions. This protection makes the $\mathrm{pH}$ value around the enzyme is lower than that of the bulk.

When we compared PPy/SDS and PDMS/PPy/SDS matrices, it is seen that presence of PDMS improves the $\mathrm{pH}$ stability of enzyme. In the case of PTSA, pH stability exhibits similarity for both matrices.

\subsection{Operational Stability of Enzyme Electrodes}

One of the most important parameter for biosensor applications of enzyme electrodes is operational stability. The operational stability of enzyme electrodes in terms of repetitive use was obtained by doing 40 measurements during the same day at optimum activity measurement conditions (Figure 3.3).

(a)

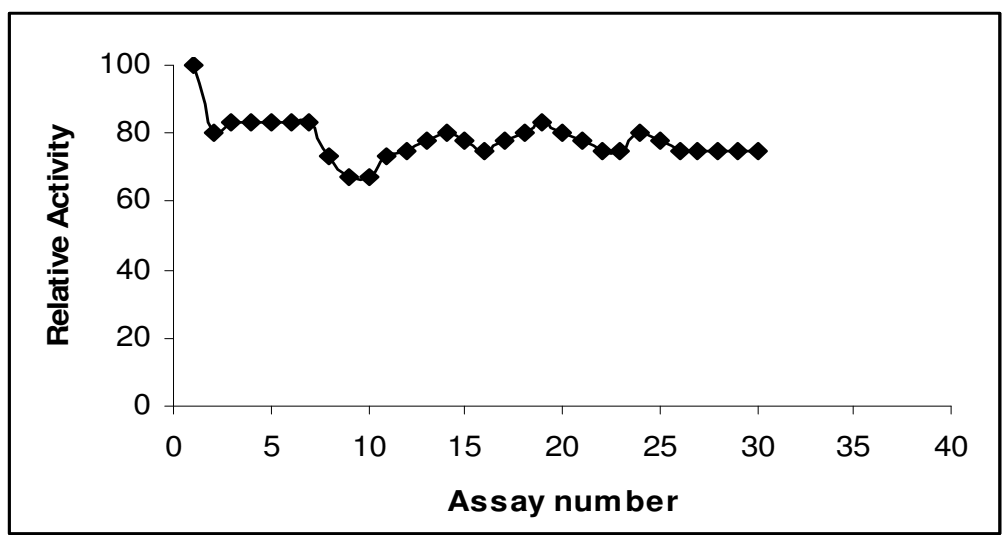


(b)

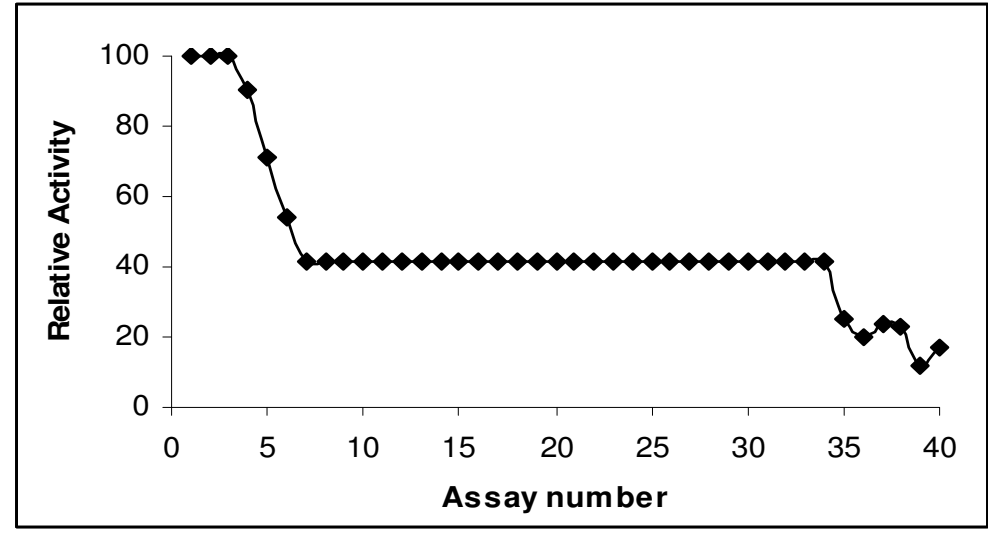

(c)

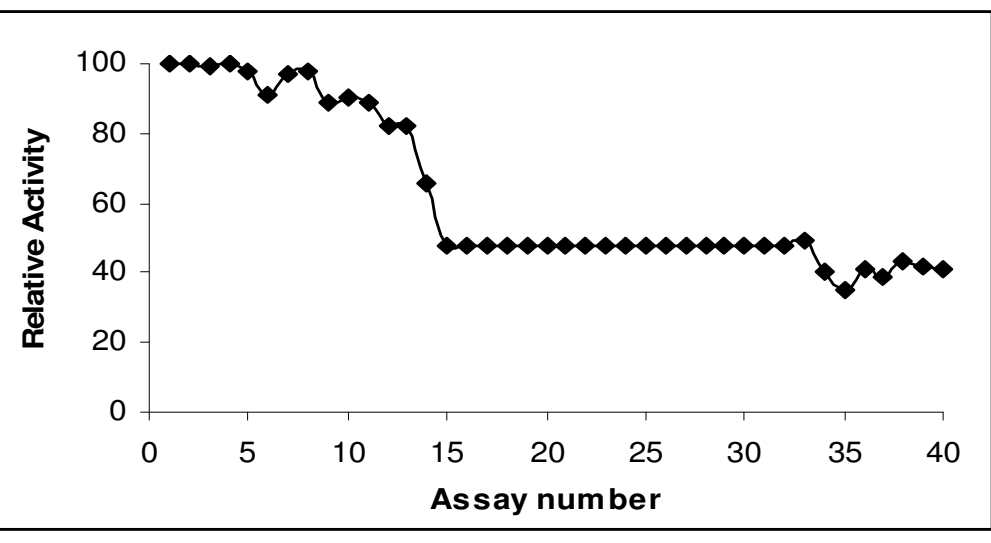

(d)

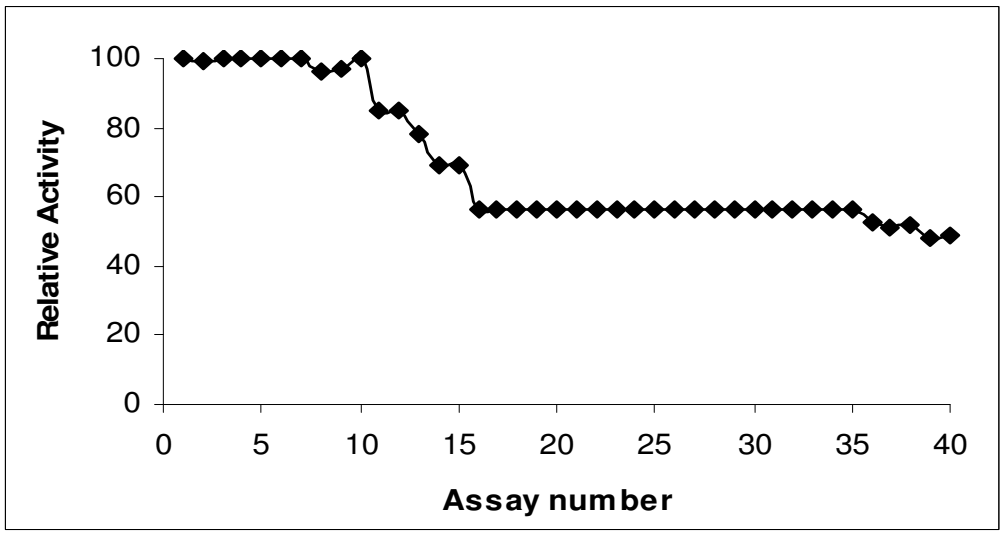

Figure 3.3 Operational stability of electrodes (a) PPy/SDS/PPO (b)PDMS/PPy/SDS/PPO(c) PPy/PTSA/PPO (d) PDMS/PPy/PTSA/PPO. 
For both PPO entrapped in PDMS/PPy and PPy matrices (with PTSA), 50\% activity loss was observed at the fifteenth use and remained constant for another 25 measurements. For PPy/SDS enzyme electrode [36], 30\% activity loss was observed at seventh use and remained constant. PDMS/PPy/SDS enzyme electrode lost $60 \%$ of its activity at the seventh use and remained constant. Furthermore, PTSA doped copolymer matrice exhibited higher stability compared to the SDS doped one.

\subsection{Shelf-life of Enzyme Electrodes}

Enzymes can easily lose their activity and storage is yet another important factor for their use as a biosensor. To determine the shelf-life of enzyme electrodes, activity of enzyme electrodes were checked for every 5 days during 35 days (Figure 3.4). During this period, enzyme electrodes were kept in citrate buffer at $4^{\circ} \mathrm{C}$.

(a)

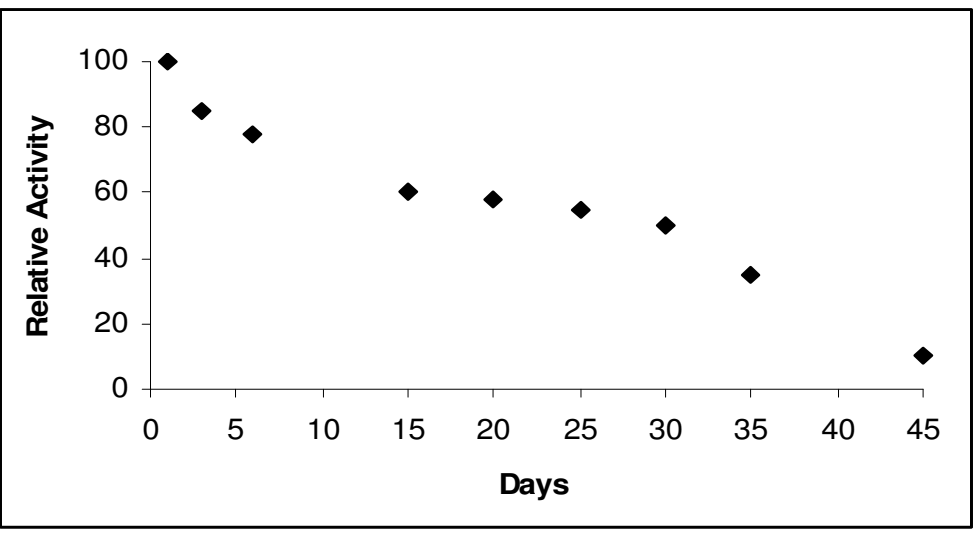


(b)

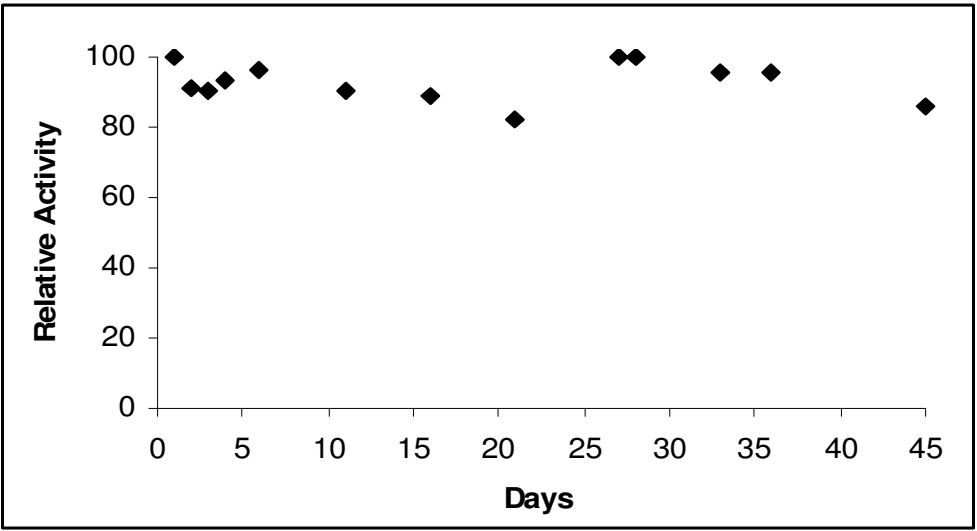

(c)

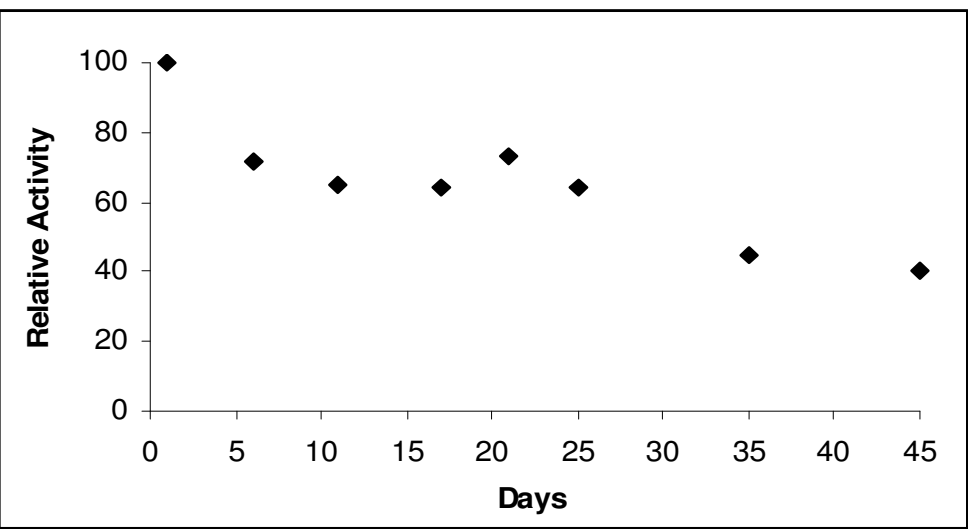

(d)

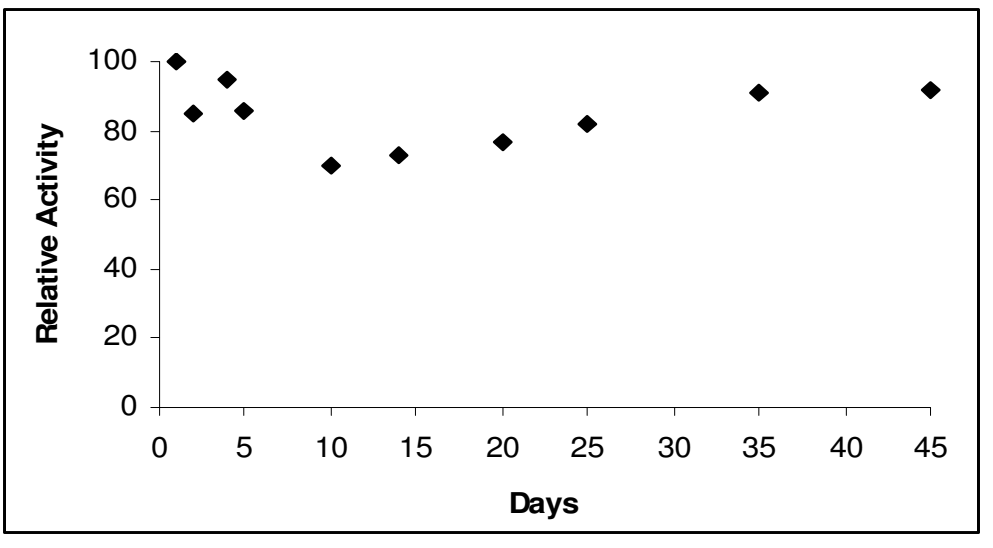

Figure 3.4 Shelf-life of electrodes (a) PPy/SDS/PPO (b) PDMS/PPy/SDS/PPO (c) PPy/PTSA/PPO (d) PDMS/PPy/PTSA/PPO. 
For PPO immobilized in PDMS/PPy, enzyme activity stays constant with small fluctations related to change in the conformation of enzyme in the matrice. PPy/PTSA enzyme electrode lost $30 \%$ of its activity in the first 5 days and there was no further appreciable activity loss within the next 30 days. PPy/SDS enzyme electrode [36] lost $40 \%$ of its activity at the fifteenth use and completely lost its activity at the forty fifth use.

\subsection{Surface Morphologies of Polymer Films}

Analysis of morphologies of films was done by using JEOL JSM - 6400 Scanning Electron Microscope. The films were synthesized under optimum conditions and washed before SEM analysis in order to remove unbound enzyme and supporting electrolyte. SEM micrographs were shown in Figure 3.5.

Surface morphologies of enzyme immobilized films are completely different when compared with the absence of enzyme. The solution sides of PDMS/PPy/SDS (Figure 3.5a), PDMS/PPy/PTSA (Figure 3.5b) and PPy/PTSA (Figure 3.5c) films exhibited cauliflower like structure which usually observed for polymers of pyrrole. The morphology of enzyme immobilized films was significantly changed for the solution sides of films for PDMS/PPy/SDS/PPO (Figure 3.5d), PDMS/PPy/PTSA/PPO (Figure 3.5e) and PPy/PTSA/PPO (Figure 3.5f). The cauliflower-like structure was damaged. 


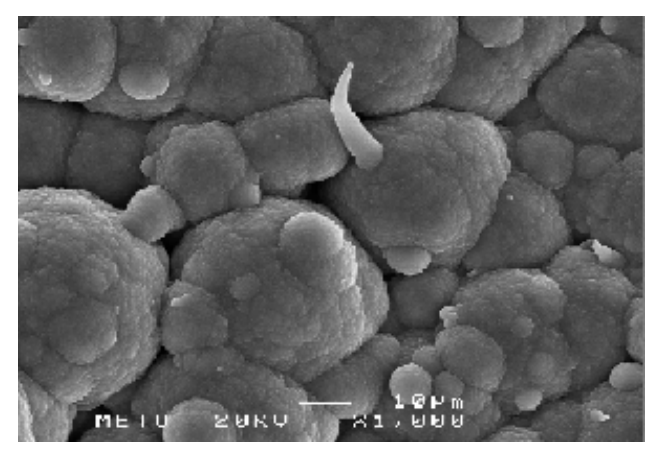

(a)

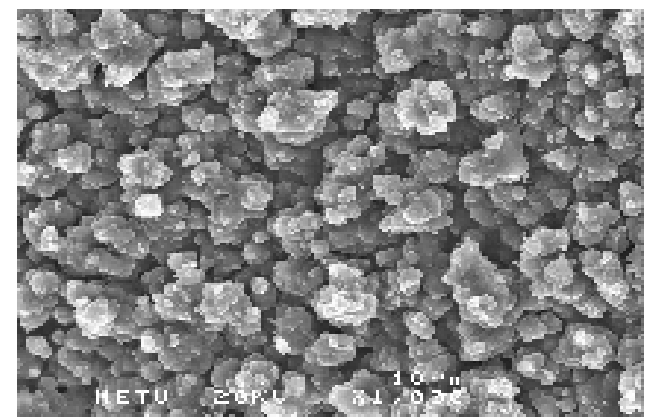

(b)

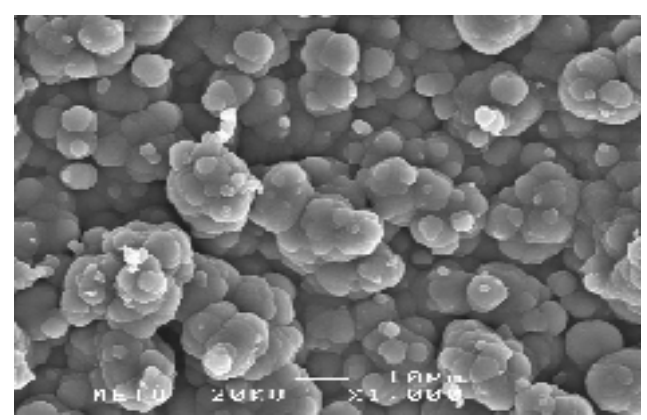

(c)

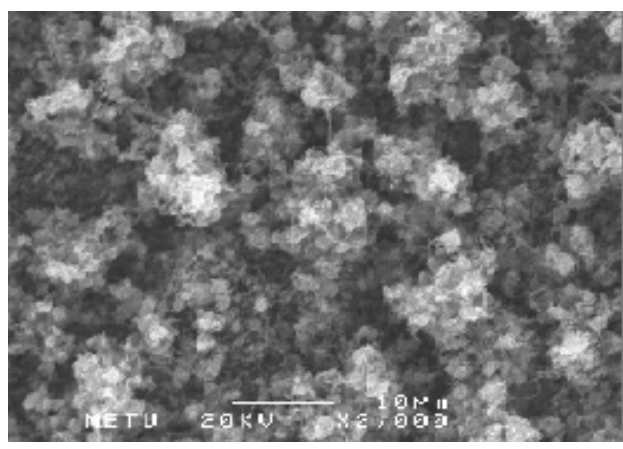

(d)

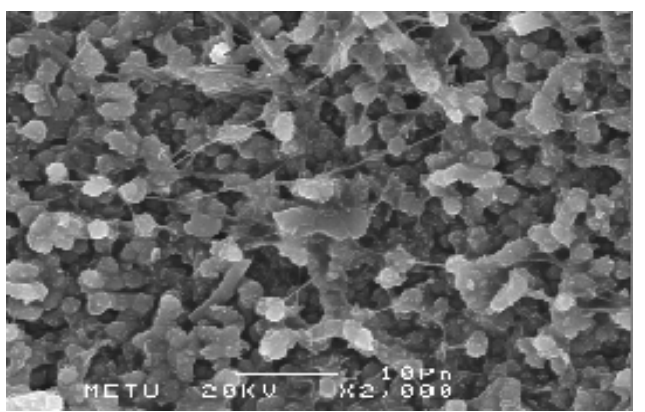

(e)

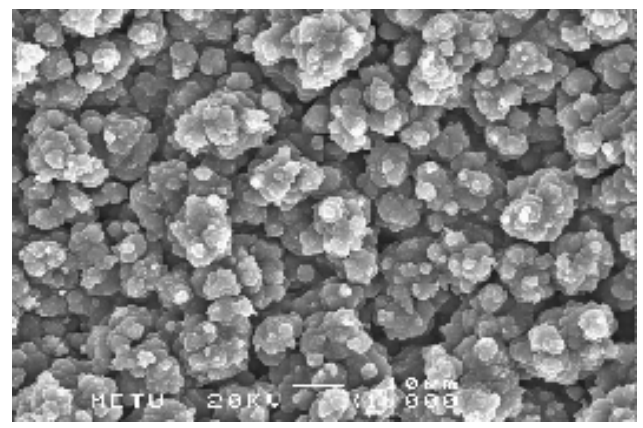

(f)

Figure 3.5 SEM micrographs of (a) PDMS/PPy/SDS (b) PDMS/PPy/PTSA

(c) PPy/PTSA (d) PDMS/PPy/SDS/PPO (e) PDMS/PPy/PTSA/PPO (f)

PPy/PTSA/PPO 
As shown in SEM pictures, both PTSA doped PPy and PDMS/PPy matrices have very compact structures. Then, diffusion of the substrate into the matrice is difficult for this matrice. This pictures support the high $\mathrm{K}_{M}$ values. Otherwise, SDS doped PDMS/PPy matrice has low $\mathrm{K}_{\mathrm{M}}$ value which supported by porous structure.

The type of supporting electrolyte is the most important parameter, since the anion of electrolyte acts as the dopant ion for the conducting copolymer. It was also concluded that the type of supporting electrolyte had strong influence on the film morphology. Also temperature and $\mathrm{pH}$ optimizations affect the morphology of films. These results revealed that PTSA provides the best immobilization medium for tyrosinase as regards to high temperature and $\mathrm{pH}$.

\subsection{Determination of Phenolic Compounds in Tea}

Green and black teas contain phenolic compounds. The major class of them is flavonoids. Generally, black tea contains theflavin derivatives and green tea contains catechin derivatives. This difference depends on the difference of growing and process for tea plant.

Phenolic amount in teas varies based on different parameters like soil type, climate, process, etc. For this reason, total phenolic amount varies in wide range, 2000-10000 mg/L [61,62].

Phenolics in green and black tea samples were determined by using enzyme electrodes. Tyrosinase catalyzes the conversion of $-\mathrm{OH}$ groups of phenolic compounds. Total $-\mathrm{OH}$ content was observed by using enzyme electrodes. The activity of enzyme electrodes in tea samples was obtained and results were reported as catechin equivalents [72,73] (CE) (Table 3.2). Total phenolics of black and green tea sample were determined with PDMS/PPy/SDS and PPy/SDS enzyme electrodes. PTSA doped enzyme electrodes were incapable of detecting phenolics because of their high $\mathrm{K}_{\mathrm{m}}$ values. 
Table 3.2

Phenolic content of black and green tea samples ${ }^{\mathrm{a}}$

\begin{tabular}{l|cc}
\hline & $\begin{array}{r}\text { Black tea (Brand C) } \\
(\mathrm{mg} / \mathrm{l})\end{array}$ & $\begin{array}{c}\text { Green tea (Brand N) } \\
(\mathrm{mg} / \mathrm{l})\end{array}$ \\
\hline PPy/SDS/PPO & 3803 & 1468 \\
PDMS/PPy/SDS/PPO & 3006 & 519.7 \\
PPy/PTSA/PPO & ND & ND \\
PDMS/PPy/PTSA/PPO & ND & ND \\
\hline
\end{tabular}

${ }^{\mathrm{a}} \mathrm{CE}$ : catechin equivalence

ND: not detected

Experimental results for phenolic content of tea are very low compared to the figures given in literature. It is known that some catechin derivatives are natural inhibitors of tyrosinase. Hence, they function as inhibitors instead of substrate inhibiting the enzymatic reaction. From the results it was shown that both SDS doped matrices are able to detect phenolics due to the differentiation of the enzyme environment. As it is seen from the SEM micrographs, presence of SDS results in larger granules which yield more permeable structures. In the presence of PTSA, matrices with smaller granules giving compact structure were obtained. These structures don't allow the flavonoids to diffuse into the matrice easily. So, enzyme electrodes fabricated in the presence of PTSA could not detect the phenolic content of tea. 


\section{CHAPTER IV}

\section{CONCLUSION}

The synthesis of polymers and copolymers of PDMS with pyrrole were achieved in the presence of different supporting electrolytes using constant potential electrolysis method. These polymers are used as immobilization matrices. Immobilization of tyrosinase in PPy and PDMS/PPy matrices were successfully achieved by electrochemical polymerization. Use of different supporting electrolytes resulted in different kinetic behaviors and surface morphologies. Kinetic parameters, optimization and morphology of enzyme electrodes were investigated.

As to the kinetic parameters, SDS was found to provide a better immobilization medium for PPO. Also SDS doped enzyme electrodes showed reasonable results in determining phenolic compounds in tea. PTSA doped enzyme electrodes were not able to detect phenolic components in tea due to high $\mathrm{K}_{\mathrm{m}}$ values. On the other hand, PTSA doped polymer matrices have good temperature and $\mathrm{pH}$ resistance characteristics compared to the SDS doped ones.

The study shows that the conducting polymers promise suitable carriers for the immobilization of PPO enzyme. The immobilization of PPO in the conducting polymers promoted enzyme electrode stability and as a result, the enzyme became more resistant to temperature and storage and became available for repeated use. For enzyme electrodes, the results are summarized as follows:

- $\mathrm{K}_{\mathrm{M}}$ value was found as $4 \mathrm{mM}$ and $\mathrm{V}_{\max } 11.2 \mu \mathrm{mol} / \mathrm{min} . \mathrm{mg}$ protein for free enzyme. $\mathrm{K}_{\mathrm{M}}$ value was found as $100,35.2,205$ and $182 \mathrm{mM}$ and $\mathrm{V}_{\max } 0.11$, 
0.03, 0.12 and $0.10 \mu \mathrm{mol} / \mathrm{min}$.electrode for PPy/SDS, PDMS/PPy/SDS, PPy/PTSA and PDMS/PPy/PTSA enzyme electrodes respectively.

- Maximum temperature was determined as $40^{\circ} \mathrm{C}$ for free PPO and PPy/SDS matrice, $60^{\circ} \mathrm{C}$ for other matrices.

- The maximum $\mathrm{pH}$ was found to be 5 for free PPO and 7 for PPy/SDS, 9 for other enzyme electrodes.

- Storage stability of PPO was improved via copolymerization. Immobilized PPO in conducting copolymers was retained its original activity in 45 days in pH 6.5 buffer at $4{ }^{\circ} \mathrm{C}$.

Immobilization of PPO often affects the stability and activity of the enzyme. The productivity of an immobilized enzyme greatly increases as a biosensor. The proposed system can be a good candidate for use in industry. Immobilization of PPO in conducting copolymers was studied as an alternative method for determination of phenolic compounds in tea samples. 


\section{REFERENCES}

1 H. Shirakawa, E.J. Louis, A.G. MacDiarmid, C.K. Chiang, A.J. Heeger, J. Chem. Soc. Chem. Commun., (1977) 578.

2 C.K. Chiang, C.R. Fischer, Y.W. Park, A.J. Heeger, H. Shirakawa, E.J. Louis, S.C. Gau, A.G. MacDiarmid, Phys. Rev. Letters, 39 (1977) 1098.

3 A.F. Diaz, Chem. Scr. 17 (1981) 142.

4 G. Tourillon, F.J. Garnier, J. Electroanal. Chem. 135 (1982) 173.

5 A.F. Diaz, K.K. Kanazawa, G.P. Gardini, J. Chem. Soc., Chem. Commun., (1979) 635.

6 G. Grem, G. Leditzky, B. Ullrich, G. Leising, Adv. Mater., 4 (1992) 36.

7 J.H. Burroughes, D.D.C. Bradley, A.R. Brown, R.N. Marks, K. MacKay, R.H. Friend, P.L. Burn, A.B. Holmes, Nature, 347 (1990) 539.

8 J. Rault-Berthelot, J. Simonet, J. Electrochem. Soc., 182 (1985) 187.

9 A.G. MacDiarmid, A.J. Epstein, Faraday Discuss. Chem. Soc., 88 (1989) 317.

10 G. Wegner, Angewandte Chemie, 20 (1981) 361.

11 U. Scherf, K. Mullen, Synthesis-Stuttgart, 1-2 (1992) 23-38.

12 J. Roncali, Chemical Reviews, 97-1 (1997) 173-205. 
13 J. A. Chilton, M. T. Goosey, Special Polymers for Electronics and Optoelectronics, UK: Chapman and Hall, (1995).

14 J. Bredas, G. Street, Acc. Chem. Research, 18-10 (1985) 309-315.

15 F. Hide, M. Diazgarcia, B. Schwartz, A. Heeger, Acc. Chem. Research, 30-10 (1997) 430-436.

16 A.J. Heeger, S. Kivelson, J.R. Schrieffer, and WP. Su., Rev. Mod. Phys., 60 (1988) 781.

17 K. Lee, A.J. Heeger., Synth. Met., 84 (1997) 715.

18 S. Kohlman, A. Zibold, D.B. Tanner, G.G. Ihas, T. Ishiguro, Y.G. Min, AG. MacDiarmid, and AJ. Epstein. Phys. Rev. Lett., 78 (1997) 3915.

19 D. Kumar, R.C. Sharma, Eur. Polym. J., 34 (1998) 1053.

20 J. A. Rogers, Z. Bao, V. R. Raju, Appl. Phys. Lett., 72 (1998) 2716.

21 N. Toshima, O. Ihata, Synth. Met., 79 (1996) 165-172.

22 H. Yan, M. Kajita, N. Toshima, Macromol. Mater. Eng., 287 (2002) 503-508.

23 Z.C. Sun, Y. H. Geng, J. Li, X. H. Wang, X. B. Jing, F. S. Wang, J. Appl. Polym. Sci., 72 (1999) 1077-1084.

24 L. Toppare, Encyclopedia of Engineering Materials Part A, Polymer Science and Technology, New York: Marcel Dekker, (1988), Vol. 1, Chapter8.

25 J. Roncali, Chem. Rev., 92-4 (1992) 711.

26 Y. Yagci, L. Toppare, Polym. Int., 52-10 (2003) 1573-1578. 
27 Ruini, F. Rossi, U. Hohenester, E. Molinari, R.B. Capaz, M.J. Caldas, Synthetic Metals, 119 (2001) 257.

28 P. M. S. Monk, R. J. Mortimer, D. R. Rosseinsky, Electrochromism; Fundamentals and Applications, VCH. Weinheim (1995).

29 B. Sankara, J. R. Reynolds, Am. Chem. Soc. Proc. Div. Polym. Mater. Sci. Eng., (1995).

30 P. Novak, K. Muller, K. Santhanam, O. Haas, Chemical Reviews, 97-1 (1997) 207281.

31 E. J. W. List, L. Holzer, S. Tasch, G. Leising, U. Scherf, K. Mullen, M. Catellani, S. Luzzati, Solid State Commun., 109 (1999) 455.

32 P. Dyreklev, M. Berggren, O. Inganas, M. R. Andersson, O. Wennerstrom, T. Hjertberg, Adv. Mater., 7 (1995) 43.

33 F. Garnier, G. Horowitz, X. Peng, D. Fichou, Adv. Mater., 2 (1990) 592.

34 R. Koenenkamp, K. Boedecker, M. C. Lux-Steiner, M. Poschenrieder, F. Zenia, C. Levy-Clement, S. Wagner, Appl. Phys. Lett., 77 (2000) 2575-2577.

35 Selampınar F., Akbulut U., Özden M.Y., Toppare L., Biomaterials, 18 (1997) 1163-1168.

36 Kıralp S., Toppare L., Yağcı Y., Int. J. Biol. Macromol., 33 (2003) 37-41.

37 Palmer T., Understanding Enzymes, Prentice Hall \& Ellis Horwood, London, (1991). 
38 R.A. Alberty, Advances in Enzymology, (1956) 17-1.

39 L. Massart, The Enzymes, Academic Press, New York (1950).

40 K. Mosbach (Ed), Methods in Enzymology, Immobilized Enzymes, Academic Press, New York (1976).

41 L. Michaelis, M. L. Menten, Biochem. Z., 49 (1913) 333.

42 H. Lineweaver, D. Burk, J. Am. Chem. Soc., 56 (1934) 658.

43 G.F. Bickerstaff, Enzymes in Industry and Medicine, E. Arnold, London, UK (1987).

44 G.F. Bickerstaff, Genet. Engineeer Biotechnologies, 15 (1995) 13.

45 Engasser, J-M. \& Horvath, C., Diffusion and kinetics with immobilised enzymes; In Applied biochemistry and bioengineering, vol. 1, ed. L.B.Wingard, (1976).

46 Bessombes J.L., Cosnier S., Labbé P., Talanta, 44 (1997) 2209-2215.

47 Marcela C. Rodriguez, Gustavo A Rivas, Anal. Chim. Acta, 459 (2002) 43-51.

48 O.R. Zaborsky, Immobilized Enzymes, CRC Press, Cleveland, (1973).

49 I. Chibata, Immobilized Enzymes; Research and Development, Wiley, New York, (1978).

50 International Union of Biochemistry, Enzyme Nomenclature, Academic Press, Orlando, (1984).

51 N. C. Foulds, C. R. Lowe, Anal. Chem., 60 (1988) 2473. 
52 E. A. H. Hall, Biosensors, Prentice Hall, Englewood Cliffs, NJ, (1991).

53 B. P. Sharma, R. A. Messing, Immobilized Enzymes for Food Processing, CRC Press, Boca Raton, Florida, 185-209, (1980).

54 W. Carasik, J. O. Carroll, Food Technol., 37 (1983) 85-91.

55 M. Pastore, F. Morisi, Methods Enzymol., 44 (1976) 822-844.

56 M. D. Trevan, Immobilized Enzymes: An introduction and applications in biotechnology, John Wiley and Sons, (1980).

57 Y. T. Yu, T. M. S. Chang, Enzyme Microbiol. Technol., 4 (1982) 327-331.

58 S. Bouchilloux, P. McMahill, H. S. Mason, J. Biol. Chem., 238 (1963) 1699.

59 R. L. Jolley, D. A. Robb, H. S. Mason, J. Biol. Chem., 244 (1969) 1593.

60 R. L. Jolley, R. M. Nelson, D. A. Robb, J. Biol. Chem., 244 (1969) 325.

61 Karakaya S., El S. N., Tas A. A., Int. J. Food Sci. Nutrition, 52 (2001) 501-508.

62 Katalinic V., Milos M., Kulisic T., Jukic M., Food Chem., 94-4 (2006) 550-557.

63 Vitaglione P., Fogliano V., J. Chr. B, 802 (2004) 189-199.

64 Bravo, L., Nutrition Reviews, 56 (1998) 317-333.

65 International Tea Committee, Annual Bulletin of Statistics, London, (1990).

66 Rio D. D., Stewart A. J., Mullen W., Burns J., Lean M. E. J., Brighenti F., Crozier A., J. Agric. Food Chem., 52-10 (2004) 2807-2815. 
67 Luczaj W., Skrzydlewska E., 40-6 (2005) 910-918.

68 Cao G., Sofic E., Prior R. L., J. Agric. Food Chem., 44-11 (1996) 3426.

69 Kalaycığlu E., Toppare L., Yağcı Y., Harabagiu V., Pintela M., Ardelean R., Simionescu B.C., Synth. Met., 97 (1998) 7.

70 Biran C., Toppare L., Tinçer T., Yağci Y., Harabagiu V., J. Appl. Polym. Sci., 86 (2002) 1663-1666.

71 Mazzocco F, Pifferi PG., Anal. Biochem., 72 (1976) 643-647.

72 Singleton V.L., Rossi J.A., Am. J. Enol. Vitic., 16 (1965) 144-158.

73 Rio D.D., Stewart A.J., Mullen W., J. Agric. Food Chem., 52 (2004) 2807-2815.

74 Alkan S., Toppare L., Yagcı Y., Hepuzer Y., J. Biomater. Sci. Polm.Ed., 10 (1999) 277. 